RECONNAISSANCE OF WATER QUALITY AT A U.S. DEPARTMENT OF ENERGY

SITE, PINELLAS COUNTY, FLORIDA

By Mario Fernandez, Jr.

U.S. GEOLOGICAL SURVEY

Water-Resources Investigations Report 85-4062

Prepared in cooperation with the

U.S. DEPARTMENT OF ENERGY

Tallahassee, Florida 


\section{UNITED STATES DEPARTMENT OF THE INTERIOR \\ DONALD PAUL HODEL, Secretary}

GEOLOGICAL SURVEY

Dallas L. Peck, Director

For additional information write to:

District Chief

U.S. Geological Survey Suite 3015

227 North Bronough Street Tallahassee, Florida 32301
Copies of this report can be purchased from:

Open-File Services Section Western Distribution Branch U.S. Geological Survey Box 25425, Federal Center Denver, Colorado 80225 (Telephone: (303) 236-7476) 
For use of readers who prefer to use metric units, conversion factors for terms in this report are listed below:

Multiply

inch (in.)

foot $(\tilde{I} t)$

foot per day ( $f t / d$ )

mile (mi)

acre

gallon (gal)

million gallons per day

(Mgal/d)

pound (1b)

micromho per centimeter

at $25^{\circ}$ Celsius

( $\mu \mathrm{mho} / \mathrm{cm}$ at $25^{\circ} \mathrm{C}$ )
By

25.4

0.3048

0.3048

1.609

4,047

3.785

3,785

0.4536

1.00
To obtain

millimeter (mm)

meter (m)

meter per day ( $\mathrm{m} / \mathrm{d})$

kilometer $(\mathrm{km})$

square meter $\left(\mathrm{m}^{2}\right)$

liter (L)

cubiç meter per day $\left(m^{3} / d\right)$

kilogram (kg)

microsiemens per centimeter at $25^{\circ}$ Celsius

$\left(\mu \mathrm{S} / \mathrm{cm}\right.$ at $25^{\circ} \mathrm{C}$ )

Temperature in degrees Fahrenheit $\left({ }^{\circ} \mathrm{F}\right)$ can be converted to degrees Celsius $\left({ }^{\circ} \mathrm{C}\right)$ as follows:

$$
{ }^{\circ} \mathrm{C}=\left({ }^{\circ} \mathrm{F}-32\right) / 1.8
$$





\section{ILLUSTRATIONS-- Continued}

Figures 1-10. Maps showing--continued:

4. Measuring points and apparent ground conductivity at the Pinellas Plant -- 7

5. Locations of wells and surface-water quality monitoring sites at the Pinellas Plant --------- 11

6. Sinkhole-type circular depressions in the vicinity of the Pinellas Plant - 13

7. Water levels, ground elevations, and depth of monitoring wells at the Pinellas Plant ------------ 18

8. Regional configuration of the water table in the surficial aquifer and direction of ground-water movement in mid-Pinellas County, May 1982

9. Potentiometric surface of the Upper Floridan aquifer in mid-Pinellas County, May 1984

10. Potentiometric surface of the Upper Floridan aquifer in mid-Pinellas County, September 1984

TABLES

Table 1. We1ls not requiring withdrawal permits in the vicinity of

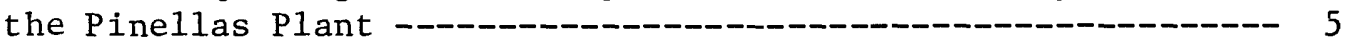

2. Geologic logs of wells - 14

3. Physical characteristics of selected geologic samples from the Pinellas Plant -- 16

4. Hydraulic conductivities for the surficial aquifer in Pinellas and Hillsborough Counties and at the Pinellas

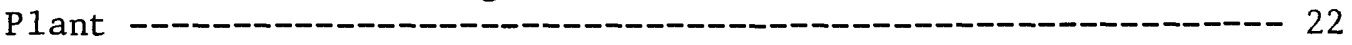

5. Selected water-quality constituents and physical characteristics for ground water from an unaltered site in central Pinellas County and wells at the Pinellas Plant

6. Selected water-quality constituents and physical characteristics for an unaltered site in central Pinellas County and ponds at the Pinellas Plant

7. Total organic carbon in ground-water, surface-water, and bottom-material samples at the Pinellas Plant 
Abstract -- -- -

Int roduction --_-_-_-_- 1

Location and description of study area -

Design and operation of liquid waste disposal -

Purpose and scope --_- 8

Approach --

Previous studies --_-_-_-_-_-_-_-_ 9

Electromagnetic survey --_-_-_- 9

Monitoring network --_- 10

Hyd rogeology --_-_- 12

Water quality --_-_- 22

Field measurements, major constituents, and nutrients --.----------- 22

Trace elements ------_---_-

Total organic carbon --_-_- 25

Organic priority pollutants -

Organic nonpriority pollutants - 27

Summary -

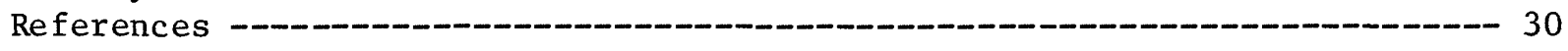

Supplement 1. Analysis by University of South Florida of 10 core

samples from the plant site --_- 33

Supplement 2. Water-quality data on field measurements and major constituents in ground water and surface water

Supplement 3. Water-quality data on nutrients in ground water, surface water, and bottom material --_-_-_- 36

Supplement 4. Water-quality data on trace elements in ground water, surface water, and bottom material - 37

Supplement 5. Water-quality data on herbicides and insecticides in ground water, surface water, and bottom material -

Supplement 6 . Water-quality data on polynuclear aromatic hydrocarbons and other hydrocarbons in ground water and surface water ------------- 40

Supplement 7. Water-quality data on polynuclear aromatic hydrocarbons and other hydrocarbons in bottom material

Supplement 8. Water-quality data on nonpriority pollutants found in ground water, surface water, and bottom material -

\section{ILLUSTRATIONS}

Figures 1-10. Maps showing:

1. Location of study area - 3

2. Drainage basins divide, general boundaries of 100-year tidal flood, and closed landfill in the vicinity of the U.S. Department of Energy's Pinellas Plant, Pinellas County, Florida --_-_---

3. Withdrawal from permitted wells located near the vicinity of the Pinellas Plant 


\title{
RECONNAISSANCE OF WATER QUALITY AT A U.S. DEPARTMENT OF ENERGY SITE, PINELLAS COUNTY, FLORIDA
}

By Mario Fernandez, Jr.

\author{
ABSTRACT
}

An electromagnetic survey for ground electrical conductivity was made to identify changes in the ground conductivity that may be due to the disposal operations. Conductivity ranged from 18 to 94 millimhos per meter, with readings of 22 to 27 millimhos per meter at the spray site. Readings between the ponds, but outside the spray area, ranged from 20 to 94 millimhos per meter. The highest reading of 94 millimhos per meter may indicate the existence of manmade conductors, such as pipes, cables, and metal drums.

Four test holes drilled into the surficial aquifer to obtain geologic information and to collect water samples for chemical analyses were converted to observation wells. Water samples from the four wells and the two disposal ponds and bottom material from the ponds were analyzed for priority and nonpriority pollutants, total organic carbon, volatile organic compounds, herbicides, insecticides, trace elements, nutrients, and major constituents. Concentrations of constituents in the water samples were (1) less than the detection limits, (2) within U.S. Environmental Protection Agency quality criteria for water, or (3) within the range of results for a designated background water-quality site. However, concentrations of 12 priority pollutants were found to be above detection limits in the bottom material for the east pond. Concentrations of these compounds, mostly coal tar derivatives, ranged from 220 to 5,500 micrograms per kilogram; the detection limit for these compounds is 10 micrograms per kilogram. Included in these compounds were anthracene, pyrenes, and chrysene, all highly suspected carcinogens.

\section{INTRODUCTION}

The Pinellas Plant of the U.S. Department of Energy has been in operation since 1956. The facility is operated by General Electric. Prior to September 1972, treated industrial wastewater and, prior to October 1973, treated sanitary waste were diverted offsite by way of a series of drainage ditches into Cross Bayou Canal. Between the preceding dates and December 1982, sanitary and industrial wastes were combined and treated at the plant by extended aeration and chlorination with ultimate disposal by spray irrigation on a 10-acre tract 
within the plant site. Two ponds on the site, the east and west ponds, were used, together with a spray-irrigation system, to treat and dispose of the combined industrial and sanitary waste. After December 1982, treated sanitary and industrial waste effluent were discharged into the Pinellas County wastewater-collection system.

The U.S. Geological Survey, in cooperation with the U.S. Department of Energy, undertook this investigation to identify ground-water and surfacewater quality conditions at the plant site. A preliminary geologic and hydrologic study was also performed. The investigation began in April 1984 and was completed in January 1985.

\section{Location and Description of Study Area}

The Pinellas Plant is on a 99.2-acre site about 6 miles north of St. Petersburg and about 5 miles southwest of 0ld Tampa Bay (fig. 1). Approximately 65 percent of the plant site is undeveloped open space. Soils at the plant site are of the Myakka and Wabasso soil series (U.S. Department of Agriculture, 1972). These poorly drained, sandy soils occur in areas that are characterized by a near-surface water table and are subject to flooding. The land surface is nearly level and the area contains grasses and some scrub pine. Land-surface altitudes range from 17 to 18 feet above sea level. Surface runoff from the Pinellas Plant is into the Starkey Road and Cross Bayou drainage subbasins (Pinellas County, 1983) (fig. 2). These subbasins drain into the Lake Seminole Bypass Canal and the Cross Bayou Canal, respectively (fig. 1). The canals drain into Cross Bayou and Long Bayou and subsequently into Boca Ciega Bay.

The tidal flood elevation (11 feet above sea level) is the altitude that tidal flooding is expected to reach on an average of once every 100 years. The flood-prone areas (fig. 2) have a 1-percent chance of being inundated during any year (Federal Emergency Management Agency, 1983a; 1983b; 1983c; 1983d).

The Pinellas Plant is in an area of mixed land use that is comprised of private homes, 1ight industry, warehouses, and small businesses. A closed landfill, owned by Pinellas County, is within 1,000 feet of the north property boundary of the Pinellas Plant site (fig. 2).

There are about 132 private wells that range from 2 to 5 inches in diameter within 8,000 feet of the Pinellas Plant (table 1). Wells 1isted in table 1 do not require a withdrawal permit from the Southwest Florida Water Management District (Southwest Florida Water Management District; 1984a) because their diameters are less than 6 inches and withdrawals are less than $100,000 \mathrm{gal} / \mathrm{d}$. Water from these wells is not for domestic consumption. However, there are 22 permitted wells south of Bryan Dairy Road that are used for water supply (Southwest Florida Water Management District, 1984b). The total permitted withdrawal for the 22 wells is $1.5 \mathrm{Mgal} / \mathrm{d}$, and the permitted daily average is about 462,000 gal. The water is used for lawns, shrubs, and nursery related irrigation demands. Location of each well and its respective well number, as related to Southwest Florida Water Management District's withdrawal permit, and daily maximum permitted withdrawal are shown in figure 3 . 


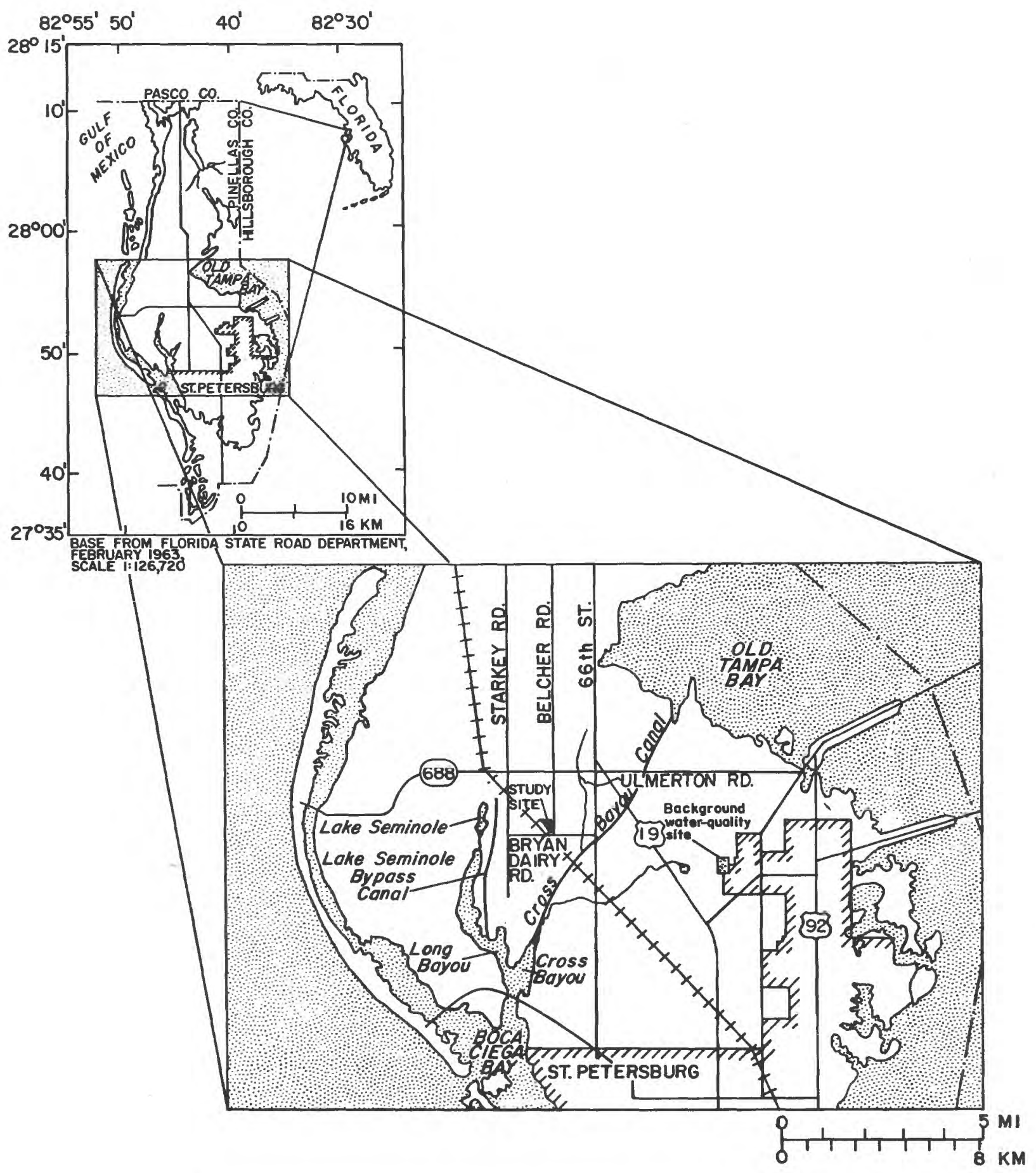

Figure 1.--Location of study area. 


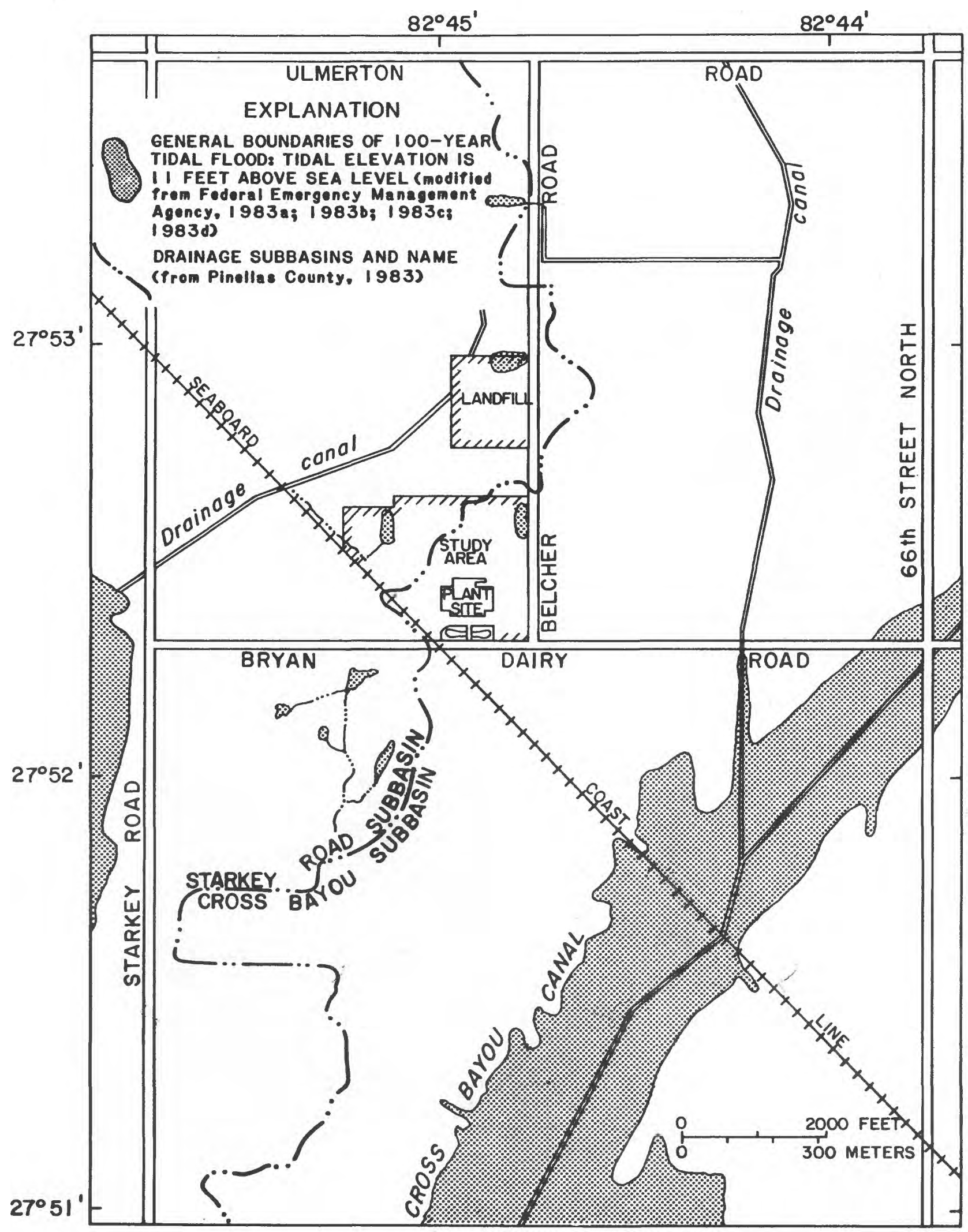

Figure 2.--Drainage basins divide, general boundaries of 100-year tidal flood, and closed landfill in the vicinity of the U.S. Department of Energy's Pinellas Plant, Pinellas County, Florida. 
Table 1.--Wells not requiring withdrawal permits in the vicinity of the Pinellas Plant -

\begin{tabular}{|c|c|c|c|c|c|c|c|}
\hline \multirow{3}{*}{ Section } & \multirow{3}{*}{ Township } & \multirow{3}{*}{ Range } & \multicolumn{5}{|c|}{ Number of we11s } \\
\hline & & & \multicolumn{4}{|c|}{ Diameter, in inches } & \multirow{2}{*}{ Total } \\
\hline & & & 2 & 3 & 4 & 5 & \\
\hline 12 & $30 \mathrm{~s}$ & $15 \mathrm{E}$ & 2 & - & 10 & - & 12 \\
\hline 13 & $30 \mathrm{~S}$ & $15 \mathrm{E}$ & 10 & 2 & 11 & 9 & 32 \\
\hline 24 & $30 \mathrm{~s}$ & $15 \mathrm{E}$ & 1 & 19 & 7 & 1 & 28 \\
\hline 7 & $30 \mathrm{~s}$ & $16 \mathrm{E}$ & - & 6 & 12 & - & 18 \\
\hline 18 & $30 \mathrm{~s}$ & $16 \mathrm{E}$ & 4 & 7 & 14 & - & 25 \\
\hline 19 & $30 \mathrm{~s}$ & $16 \mathrm{E}$ & 4 & 5 & 8 & - & 17 \\
\hline
\end{tabular}

Pinellas County has a subtropical climate that is characterized by warm, humid summers with frequent afternoon thundershowers and by mild, dry winters with occasional showers associated with cold fronts. The normal yearly rainfal1, based on the period 1951 through 1980, is 52.10 inches. Some rainfal1 generally occurs during each month of the year, but approximately 63 percent occurs from June through October (U.S. Department of Commerce, 1984). The average annual temperature for the area is about $73.6^{\circ} \mathrm{F}$. The average monthly temperature ranges from about $62^{\circ} \mathrm{F}$ in January to $83^{\circ} \mathrm{F}$ in July and August (U.S. Department of Commerce, 1984).

Design and Operation of Liquid Waste Disposal

Four types of 1iquid waste are generated at the Pinellas Plant: (1) chemical, (2) liquids potentially containing tritium, (3) sanitary, and (4) industrial. The chemical waste has always been separated for special handling, whereas the other wastes, following treatment, have been combined for release from the plant site (Applegate, 1983, p. 12).

Prior to September 1972, treated industrial waste (neutralized and combined with liquids potentially containing tritium) and, prior to October 1973, treated sanitary wastes (extended aeration and chlorination) were discharged offsite by way of a series of drainage ditches into the Cross Bayou Canal. Between September 1972 and December 1982, the treated industrial waste, and October 1973 and December 1982, the treated sanitary waste were discharged to an onsite, 2.60-Mgal detention pond (west pond, fig. 4) and subsequently sprayed onto a 10-acre tract. A subsurface drainage system under the irrigated field collected and discharged the percolate to a 3.24Mgal detention pond (east pond, fig. 4). Percolate from the east pond was then discharged in batches through a county drainage system to the Cross Bayou Canal. 


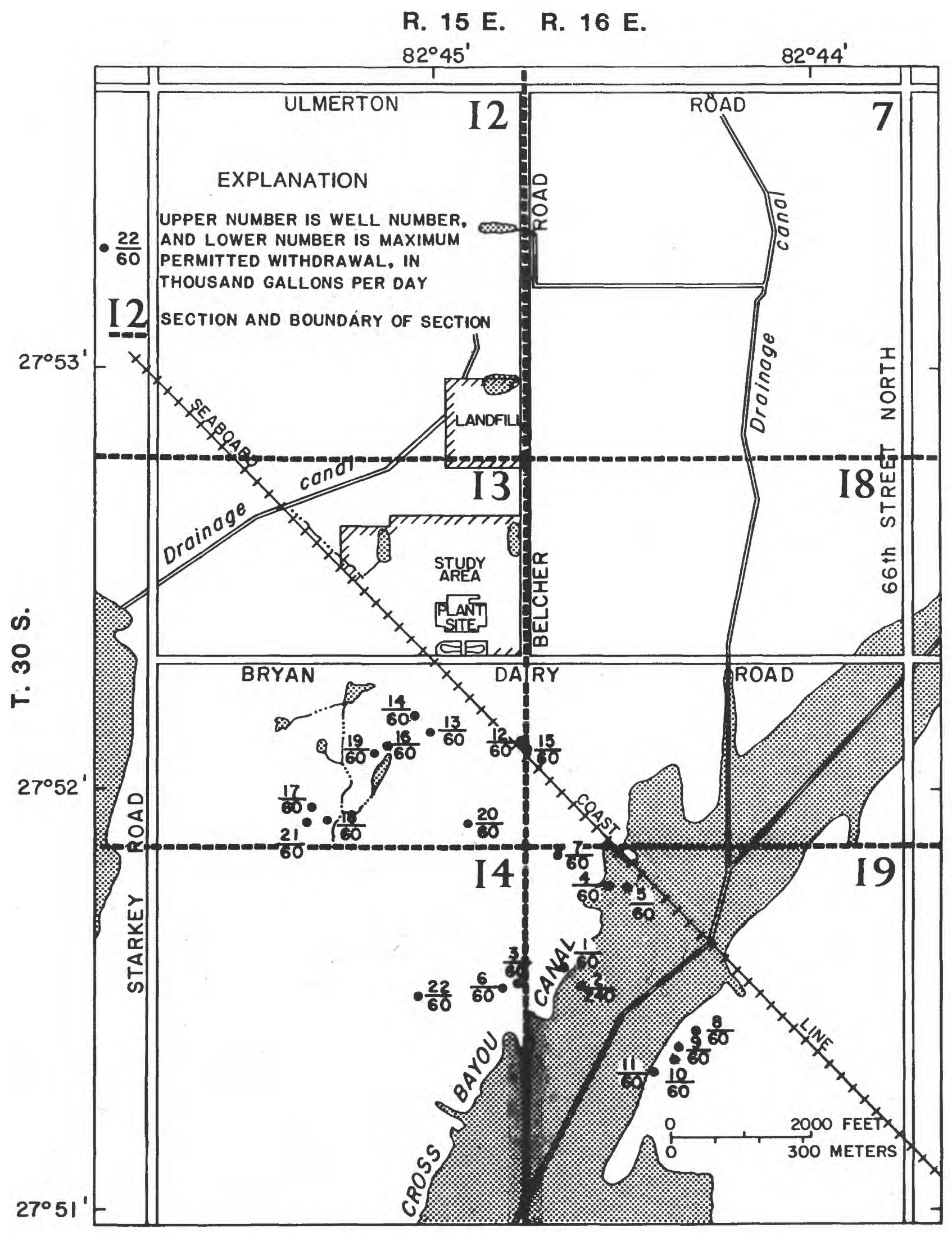

Figure 3.--Withdrawal from permitted wells located near the vicinity of the Pinellas Plant. 


\author{
EXPLANATION \\ 25 MEASURING POINT AND APPARENT GROUND
CONDUCTIVITY, IN MILLIMHOS PER METER \\ AREA WHERE APPARENT GROUND CONDUCTIVITY \\ WAS GREATER THAN IOO MILLIMHOS PER METER
}

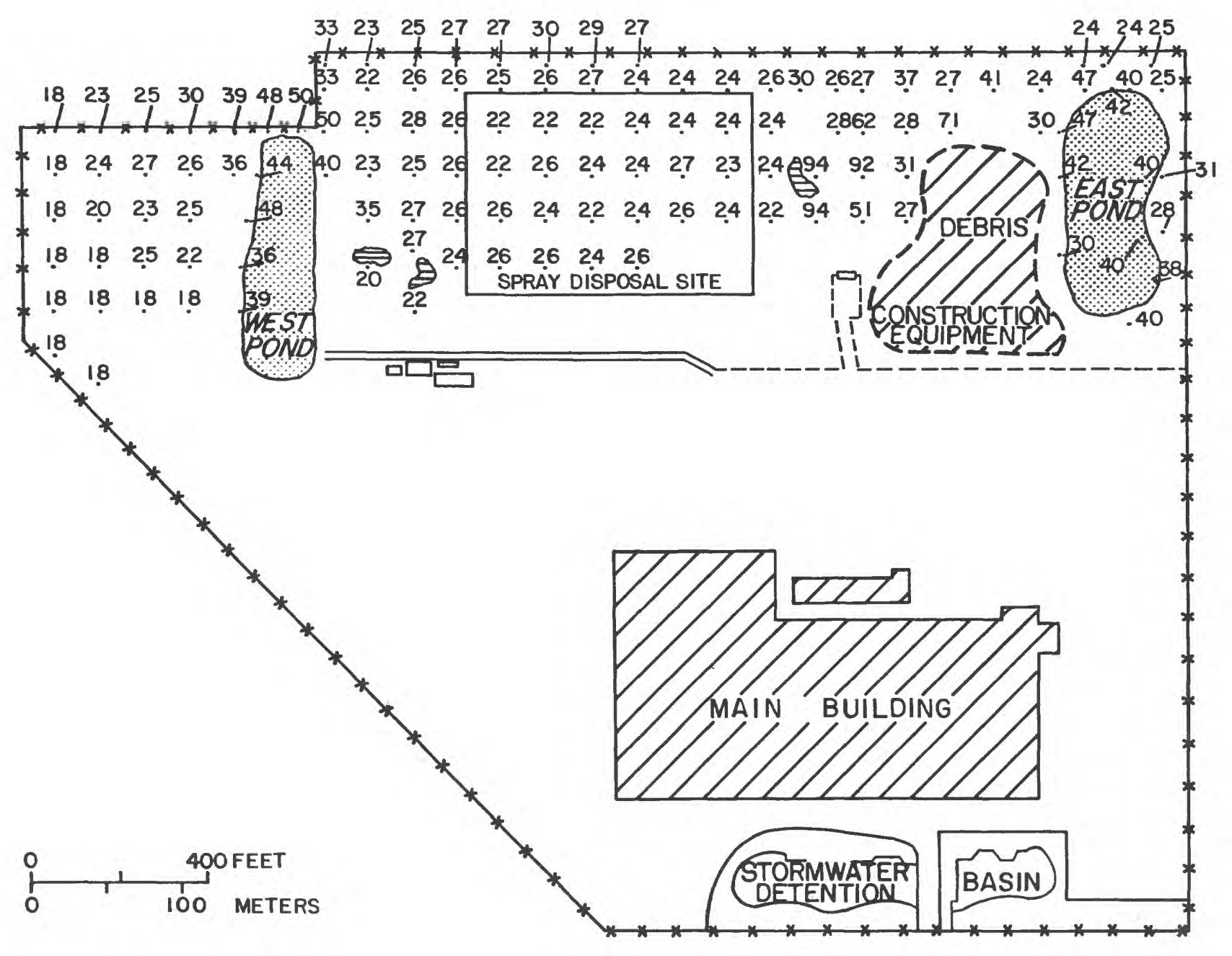

Figure 4.--Measuring points and apparent ground conductivity at the Pinellas Plant. 
Since December 1982, untreated sanitary wastes, industrial wastes treated to maintain a pH between 6.0 and 8.5 , and water that contains limited amounts of tritium are piped to the county-owned South Cross Bayou Pollution Control Facility (Applegate, 1983). Before effluent that contains tritium is permitted to leave the site, it must meet standards set forth in the U.S. Department of Energy's Order 5480.1 (U.S. Department of Energy, 1981a). This standard for tritium is 0.1 microcurie per milliliter $(\mu \mathrm{Ci} / \mathrm{mL})$. Discharge of tritium from the Pinellas Plant into the county's sewage-collection system during 1983 averaged 0.009 percent of the standard (U.S. Department of Energy, 1983) or $9.0 \times 10^{-6} \mu \mathrm{Ci} / \mathrm{mL}$. The standards for the release of tritium to surface waters outside the site are set forth in the DOE Order 5480.1 as $0.003 \mu \mathrm{Ci} / \mathrm{mL}$. The release of tritium into surface water from the Pinellas Plant during 1983 averaged 0.05 percent of that standard (U.S. Department of Energy, 1983) or $1.5 \times 10^{-6} \mu \mathrm{Ci} / \mathrm{mL}$.

Chemical wastes, as before, are separated for special handling. The chemical wastes are stored and treated in compliance with the Resources Conservation and Recovery Act (RCRA) of the Federal Government (became effective in the fall of 1980) and then transported by tank truck to a permitted offsite disposal facility.

The following is a list of the constituents (including BOD-5) in the industrial waste effluent (U.S. Department of Energy, 1983):

$\begin{array}{lll}\text { Arsenic } & \text { Chromium, total } & \text { Iron } \\ \text { Barium } & \text { Chromium, trivalent } & \text { Lead } \\ \text { BOD-5 } & \text { Chromium, hexavalent } & \text { Manganese } \\ \text { Boron } & \text { Copper } & \text { Mercury } \\ \text { Cadmium } & \text { Cyanide } & \end{array}$

\section{Purpose and Scope}

The purpose of this study was to make an initial assessment of the water quality of a site that was used for disposal of treated combined sanitary and industrial wastes in order to identify any problem areas requiring further study, such as areas with degraded or contaminated ground water. Specific objectives of this study were as follows:

1. Complete a search of the literature and records for geologic and hydrologic data of the site and surrounding area;

2. Provide an initial assessment of the hydrogeology and direction of ground-water movement;

3. Identify inorganic constituents and organic compounds that may be present in the ground water; and

4. Perform preliminary analyses to define the quality of onsite water and establish baseline water-quality conditions at the study site. 


\section{Approach}

This report presents the results of test drilling and analyses of water from wells drilled into the surficial aquifer. Four test holes were drilled to determine the hydrology and geology of the area and were later converted to observation wells. Driller's logs for wells and laboratory analyses of cores from one well were used to identify the geologic and hydrologic properties of the aquifer material. Laboratory determinations included porosity, ionexchange capacity, grain-size distribution, hydraulic conductivity, and claymineral identification. Water levels were measured in wells to determine the depth to water and altitude of the water table. Information from a literature survey was used to determine the general direction of movement of water in the surficial aquifer. Electromagnetic methods were used to define the ground electrical conductivity as an aid in locating variations in water quality and to locate buried ferrous materials. Chemical analyses of water samples from the four wells and the two detention ponds and from bottom material collected from the ponds were made to determine concentrations of major constituents, nutrients, $\mathrm{pH}$, specific conductance, herbicides, insecticides, total organic carbon, volatile organic compound, and selected other priority pollutants.

\section{Previous Studies}

The Pinellas Plant has been studied by several consultants and in-house groups. A pavement and drainage study by Housel-Terpening and Associates (1979) presents borehole data for depths of up to 12 feet. Environmental Associates, Inc. (1980), made an engineering study and evaluation of the waste-management system at the plant. They analyzed samples from the sanitary wastewater before and after collection and treatment, industrial wastewater, the retention pond system, solid wastes, and stormwater and evaluated changes in treatment methods needed to meet existing and proposed Federal, State, and local regulations. An environmental assessment by Applegate (1983) describes the operations of the Pinellas Plant, discusses the locale of the plant, and assesses the actual and possible impacts of plant operation on the surrounding environment. The report concluded that there was not any evidence of adverse environmental effects due to plant operations or any cumulative or long-term effects on the surrounding area.

The U.S. Department of Energy (1981b; 1982; 1983) published environmental monitoring reports on the plant. Those reports present monitoring data on radioactive gaseous effluents and solid waste and also on nonradioactive effluents and solid waste. Also, data were presented for onsite and offsite air monitoring of tritium and plutonium and of offsite surface-water monitoring of tritium.

\section{ELECTROMAGNETIC SURVEY}

An electromagnetic survey for ground electrical conductivity was made of the area to assist in locating sites where test holes would be drilled. A preliminary electromagnetic survey for ground conductivity was made of the spray site and of areas around the ponds to determine relative differences in 
the ground conductivity that might have been caused by the spray and disposal system. For purposes of this study, ground conductivity means the bulk or integrated conductivity of the upper 15 to 18 feet of aquifer material. Although most aquifer materials have a very low conductivity and can be considered to be insulators, there are some metallic minerals and silicate clay minerals in the aquifer materials that have high conductivities. The bulk conductivity of saturated aquifer materials (pore fluid conductivity) is orders of magnitude higher than that of the minerals from which they are composed because of the generally greater conductivity of water (Stewart, 1981). Pore fluid conductivity is directly related to the amount of dissolved minerals that the fluid contains or, in the case of contaminants, the concentration of dissolved contaminants in the fluid. A portable electromagnetic unit with a transmitter coil that induces circular eddy current loops in the ground was used for the survey. The magnitude of the current loops is proportional to the ground electrical conductivity in the vicinity of the loop.

The area was surveyed in 100-foot grids. Although measurements were continuous, only readings at 100-foot intervals were recorded. Any high readings were also recorded. The results of the survey are presented in figure 4. Although most conductivities ranged from 18 to $94 \mathrm{mmhos} / \mathrm{m}$ (millimhos per meter) at the site, there were areas that had apparent conductivities greater than $100 \mathrm{mmhos} / \mathrm{m}$ (fig. 4). These were isolated readings. These readings may indicate the existence of underground conductors, such as pipes, cables, and metal drums (Geonics Limited, 1984, p. 17). Readings at the spray disposal area (fig. 4) ranged from 22 to $27 \mathrm{mmhos} / \mathrm{m}$, whereas readings for the rest of the area between the ponds ranged from 20 to $94 \mathrm{mmhos} / \mathrm{m}$. Preliminary findings indicate that the spray disposal area does not differ from the rest of the study area. A large area west of the east pond (fig. 4) could not be measured because of construction debris on the ground that caused interference in the readings of the instrument. An area west of the west pond (fig. 4) had conductivities that ranged from 18 to $30 \mathrm{mmhos} / \mathrm{m}$. This area could be used in future studies as the baseline ground conductivity for the area. Conductivity readings around the east and west ponds ranged from 28 to 47 and 36 to $50 \mathrm{mmhos} / \mathrm{m}$, respectively. Because metals can cause artificially high readings, measurements along the property line were taken at least 50 feet from the metal boundary fence.

\section{MONITORING NETWORK}

Four test holes (DOE-1 through DOE-4, fig. 5) were drilled into the surficial aquifer to obtain: (1) lithologic samples to determine physical properties of the geologic units, (2) levels of the water table, and (3) samples for water-quality analysis to define baseline conditions. The test holes were later converted to observation wells. Eleven 1.5-inch diameter PVC cased test wells (sites 5 through 8 and 10 through 12, fig. 5) in existence prior to this study were also incorporated into the network of wells. These 11 test wells were established at depths of 15 and 30 feet below land surface and are designated by $S$ (shallow) and $D$ (deep), respectively (fig. 5).

The four test holes were drilled using a hollow-stem auger. The test holes were converted to observation wells using 2-inch PVC pipe finished with 0.01-inch slotted 2-inch PVC screen. Well depths ranged from 23 to 39.5 feet 


\section{EXPLANATION}
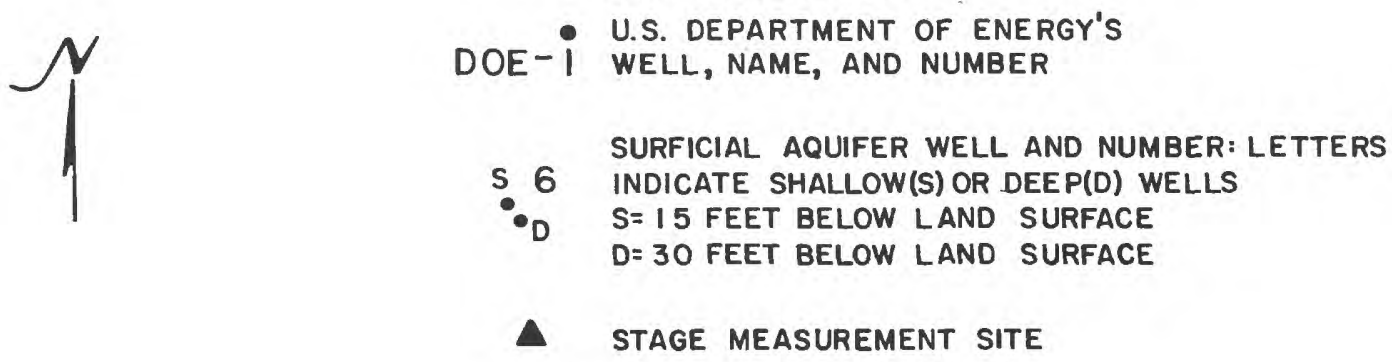

a $H^{-1}$ HORIZONTAL CORING AND NUMBER

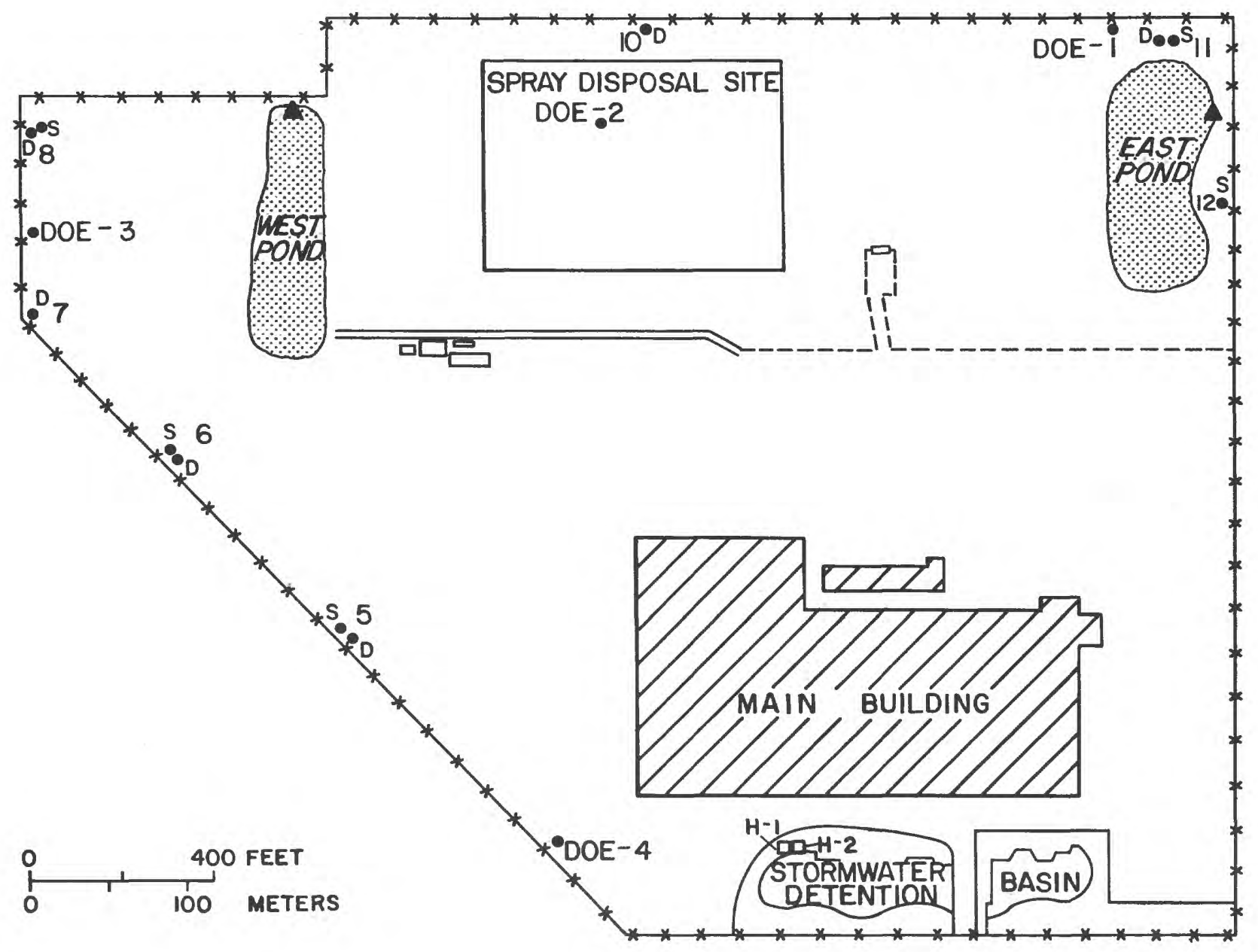

Figure 5.--Locations of wells and surface-water quality monitoring sites at the Pinellas Plant. 
of screen. All couplings and end caps on the screen were installed without PVC cement to prevent contamination of ground-water samples by components of the PVC cement.

We11 DOE-1 was used to define the quality of water downgradient from a boat manufacturer next to the northeast corner of the study site. Well DOE-2 was used to establish ground-water quality in the former spray-irrigation area. We11 DOE-3 was constructed to determine ground-water quality along the west side of the study site, and well DOE-4, although not in close proximity to the building, monitors migration of ground water moving southwest from beneath the main building.

\section{HYDROGEOLOGY}

The three uppermost stratigraphic units that underlie the Pinellas Plant in descending order are: (1) undifferentiated surficial deposits of Pleistocene age; (2) the Hawthorn Formation of middle Miocene age; and (3) the Tampa Limestone of early Miocene age (Heath and Smith, 1954). The surficial deposits, the calcareous sandy clay of the Hawthorn Formation, and the clays of the Tampa Limestone are generally unconsolidated.

Numerous small, circular depressions that are characteristics features of sinkhole areas (Sinclair, 1982, p. 3) occur in the vicinity of the plant (fig. 6), although there are not any that occur on the plant site. These depressions may indicate possible conduits between the surficial aquifer and the Upper Floridan aquifer. The locations of these circular depressions are based on 1926 aerial photos of Pinellas County (Hamilton, 1926).

Core samples from the four test holes were collected and described in the field. The descriptions are presented in table 2. The upper layer of sand, as reported in table 2, ranges in thickness from about 25 to 40 feet and particle size ranges from very fine to medium. A gray to blue-gray clay layer occurs beneath the sand. The clay is silty and sandy. Inclusions of chert fragments, limestone fragments, and subround black pebbles occur in the clay.

The core samples were analyzed by the Department of Geology of the University of South Florida, Tampa. A description of the methods used in the analyses is presented in Supplement 1 . Ten core samples from we11 DOE-4 (fig. 5) were analyzed for physical characteristics and results are presented in table 3. Particle size ranged from 69.7 to 98.1 percent sand and gravel, 0 to 3.4 percent silt, and 1.9 to 26.9 percent clay. The clay fraction contained kaolinite, smectite, chlorite, quartz, gibbsite, and illite. The total porosity ranged from 31.9 to 42.8 percent for the sand samples and was 52.8 percent for the single clay sample. The vertical hydraulic conductivity was between 10.2 and $73.7 \mathrm{ft} / \mathrm{d}$ at $22^{\circ} \mathrm{C}$, with the exception of one core (clay) that was estimated to be about $0.2 \mathrm{ft} / \mathrm{d}$. The cation exchange capacity, or the "excess of counter ions in the zone adjacent to the charged surface or layer which can be exchanged for other cations" (Freeze and Cherry, 1979, p. 128), ranged from 0.37 to $3.4 \mathrm{meq} / 100$ grams (milliequivalents per 100 grams) for the sand samples and was 11.9 meq/100 grams for the clay sample. The ion exchange capacity can be used to determine the extent to which the sediments can bind dissolved metals that could leak into the ground-water system from a spill in the plant or leakage from the drainage system beneath the plant. 


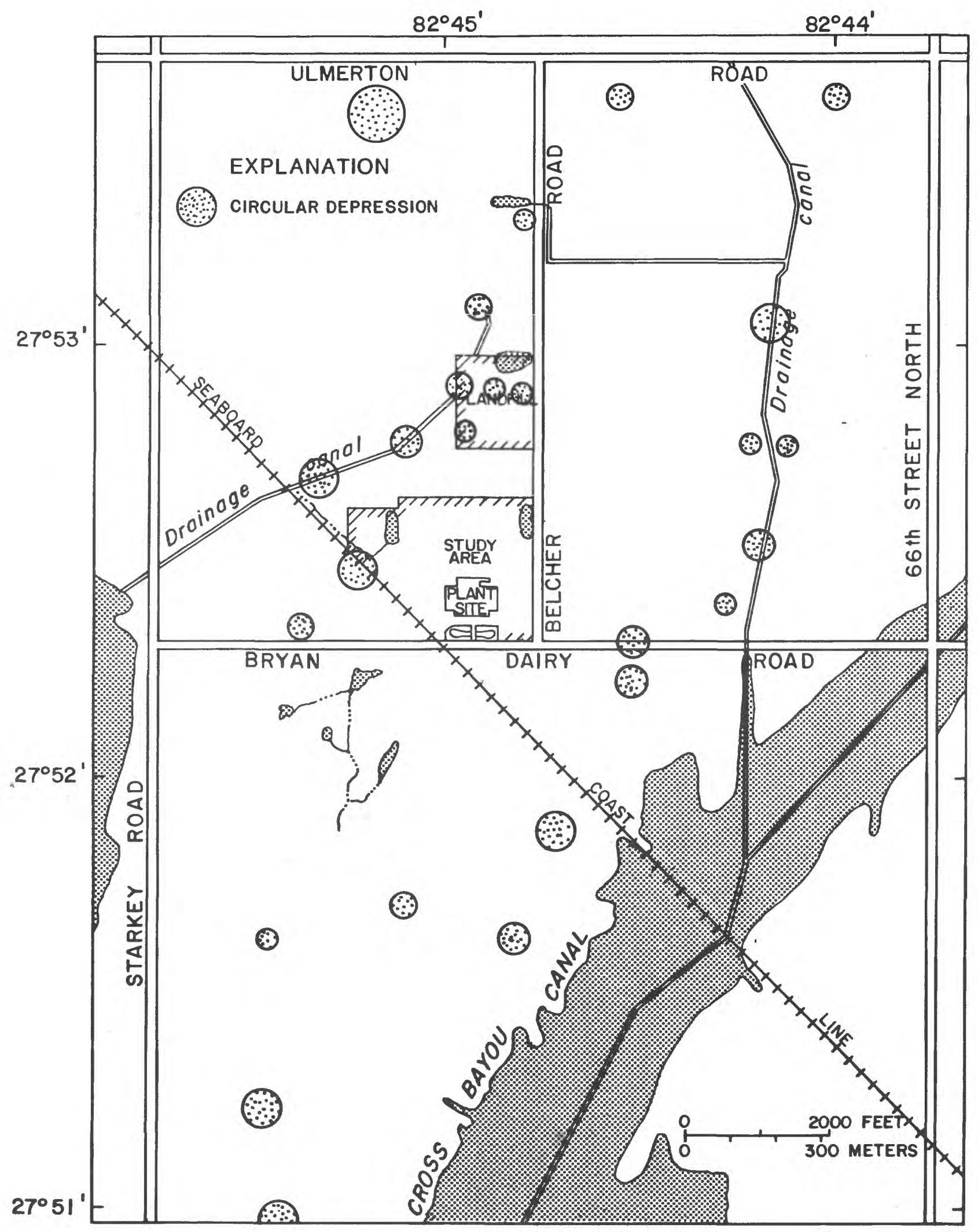

Figure 6.--Sinkhole-type circular depressions in the vicinity of the Pinellas Plant. 
Table 2.--Geologic logs of wells

Material $\quad \underline{\begin{array}{c}\text { Thickness } \\
\text { (feet) }\end{array}}$\begin{tabular}{c}
$\begin{array}{c}\text { Depth } \\
\text { (feet) }\end{array}$ \\
\hline
\end{tabular}

We11 DOE-1, station number 2752390824448.01

Sand, very fine to medium, silty, mottled, light

and dark brown -----

Sand, very fine to medium, silty, mottled, light

and dark brown, occasional shell

and dark brown, possible organics --_-_-_--_---

Sand, very fine to medium, silty, dark brown, traces of clay

Sand, very fine to medium, some silt, light

grayish brown, occasional dark minerals or

organic grains - -

$\mathrm{Clay}$, silty, gray with white streaks, some sand ------

$5 \quad 10$

5

We11 DOE-2, station number 2752370824501.01

Sand, very fine to medium, silty, clayey, brown ------ 6

Sand, very fine to medium, silty, clayey, brown -...- 5

Sand, very fine to medium, silty, clayey, blue-gray

with shell fragments - 12

Sand, very fine to medium, silty, brown

Sand, very fine to medium, silty, brown -

Sand, very fine to medium, silty, brown -

Clay, silty, sand, gray-blue with numerous chert

fragments - 4

We11 DOE-3, station number 2752370824514.01

Sand, very fine to medium, silty, light to dark brown --

Sand, very fine to medium, silty, shell fragments ----

Sand, very fine to medium, silty, clayey blue-gray

with occasional shell fragments -

Clay, silty, sandy, blue-gray with shell fragments ---

Sand, very fine to medium, silty, brown -

Sand, very fine to medium, silty, clayey with shell fragments - -

Sand, very fine to medium, silty, clayey, gray -------

Clay, silty, sandy, blue-gray, mottled, with some chert fragments 
Table 2.--Geologic logs of wells--Continued

\begin{tabular}{ll} 
Material & $\begin{array}{c}\text { Thickness } \\
\text { (feet) }\end{array} \quad \begin{array}{l}\text { Depth } \\
\text { (feet) }\end{array}$ \\
\hline
\end{tabular}

We11 DOE-4, station number 2752218024502.01

Sand, very fine to medium, silty brown with some

black organic matter --

Sand, very fine to medium, silty, brown with

traces of black organic matter -_-_-_-_-_-

Sand, very fine to medium, silty, light brown -.-------

Sand, very fine to medium, silty, brown with shell

fragments --_-_-_-_-_-_-_-_-_-_-_-_-_-

Sand, very fine to medium, very silty, dark brown ----

Sand, very fine to medium, less silty, light brown with shell fragments --

Sand, very fine to medium, silty, dark brown with numerous shell fragments

Clay, silty, sandy, dark brown, mottled with blue and white limestone fragments and round to subround black pebbles
2

2

$7 \quad 9$

$4 \quad 13$

14

$4 \quad 18$

12

30

10

40

2

42

Two horizontal core samples, $\mathrm{H}-1$ and $\mathrm{H}-2$ (table 3, fig. 5), were collected at a depth of 8.0 feet below land surface at recently (1984) excavated stormwater detention basins (fig. 5). Particle size was 95.5 and 96.8 percent sand and gravel, 0.3 and 2.5 percent silt, and 2.0 and 2.9 percent clay. Total porosity was 42.9 and 50.3 percent. Cation exchange capacity or mineralogy of clay fraction was not determined.

There are three hydrologic units underlying the study area (Hickey, 1982, p. 8). These units, in descending order, are: (1) the surficial aquifer--an unconfined, permeable sand layer of fine to very fine sand and she11; (2) the upper confining bed of the Upper Floridan aquifer--a semipermeable layer of marl and clay; and (3) the Upper Floridan aquifer. The thickness of the surficial aquifer ranges from about 25 to 40 feet (table 2). The thickness of the upper confining bed has been reported to be between 50 and 100 feet (Buono and others, 1979), and the depth to the top of the Upper Floridan aquifer is about 100 feet (Buono and Rutledge, 1979). The only unit tested in this study was the surficial aquifer.

A comparison of hydraulic conductivities for the surficial aquifer at the Pinellas Plant and previously reported conductivities in Pinellas and Hillsborough Counties (Hickey, 1982) is presented in table 4. The vertical hydraulic conductivities at the Pinellas Plant ranged from 0.2 to $73.7 \mathrm{ft} / \mathrm{d}$. Horizontal conductivities were 22.7 and $42.5 \mathrm{ft} / \mathrm{d}$ in two samples. The vertical and horizontal conductivities reported for Hillsborough and Pinellas Counties ranged from 0.36 to $13 \mathrm{ft} / \mathrm{d}$ and 13 to $33 \mathrm{ft} / \mathrm{d}$, respectively. The test used to determine the hydraulic conductivities in core samples from the 
Table 3.--Physical characteristics of selected [u, micron; ft/d, feet per day;

\begin{tabular}{|c|c|c|c|c|c|c|}
\hline \multirow[b]{2}{*}{ We 11} & \multirow[b]{2}{*}{$\begin{array}{l}\text { Test } \\
\text { hole }\end{array}$} & \multirow{2}{*}{$\begin{array}{l}\text { Depth } \\
\text { below } \\
\text { land } \\
\text { surface } \\
\text { (feet) }\end{array}$} & \multicolumn{3}{|c|}{ Particle size analysis } & \multirow[b]{2}{*}{$\begin{array}{c}\text { Porosity, } \\
\text { total, } \\
\text { (percent) }\end{array}$} \\
\hline & & & $\begin{array}{l}\text { Percent } \\
\text { sand } \\
\text { and } \\
\text { grave1 }\end{array}$ & $\begin{array}{l}\text { Percent } \\
\text { silt } \\
(63- \\
3.9 \mu)\end{array}$ & $\begin{array}{l}\text { Percent } \\
\text { clay } \\
(<3.9 \mu)\end{array}$ & \\
\hline \multirow[t]{8}{*}{275221082450201} & DOE-4 & $5-6.5$ & 92.5 & 0.6 & 7.0 & 31.9 \\
\hline & & $10-11.5$ & 91.2 & .9 & 7.9 & 41.2 \\
\hline & & $15-16.5$ & 89.8 & 1.2 & 9.0 & 38.6 \\
\hline & & $20-21.5$ & 84.8 & .6 & 14.6 & 37.2 \\
\hline & & $25-26$ & 96.2 & 1.0 & 2.8 & 42.8 \\
\hline & & $30-31.5$ & 98.1 & 0 & 1.9 & 35.8 \\
\hline & & $35-36.5$ & 95.5 & .5 & 4.0 & 39.9 \\
\hline & & $40-41.5$ & 69.7 & 3.4 & 26.9 & 52.8 \\
\hline 275220082450001 & $\mathrm{DOE}-\mathrm{H} 1$ & 8.0 & 95.5 & 2.5 & 2.0 & 42.9 \\
\hline 275220082450001 & DOE-H2 & 8.0 & 96.8 & .3 & 2.9 & 50.3 \\
\hline
\end{tabular}

Pinellas Plant was run on a Soil Test constant head permeameter (Supplement 1), whereas the reported values for Hillsborough and Pinellas Counties are based on triaxial permeameters and pumping tests. Variations in techniques might yield different results.

The 15 wells finished in the surficial aquifer and the 2 ponds were used to determine the altitude of the water table in the surficial aquifer. The results of these water-1evel measurements are presented in figure 7 . Groundwater surface altitudes ranged from 13.8 to 17.9 feet above sea level. Water levels in the east and west ponds were 14.1 and 16.9 feet above sea level, respectively. Causseaux (1985, p. 27) reported that the seasonal fluctuation of the water table in Pinellas County ranges from about 1 to 4 feet. The regional configuration of the water table in relation to the Pinellas Plant 
geologic samples from the Pinellas Plant

meq/100 g, milliequivalents per 100 grams]

\begin{tabular}{|c|c|c|c|c|c|c|c|}
\hline \multicolumn{2}{|c|}{$\begin{array}{l}\text { Hydraulic } \\
\text { conductivity } \\
\text { at } 22^{\circ} \mathrm{C}\end{array}$} & \multirow{2}{*}{$\begin{array}{c}\text { Cation } \\
\text { exchange } \\
\text { capacity } \\
\text { (meq/100 g } \\
\text { sample) }\end{array}$} & \multicolumn{5}{|c|}{$\begin{array}{l}\text { Mineralogy of clay fraction } \\
(<2 \mu) \text {, in percent }\end{array}$} \\
\hline $\begin{array}{l}\text { Vertical } \\
(\mathrm{ft} / \mathrm{d})\end{array}$ & $\begin{array}{l}\text { Hori- } \\
\text { zontal } \\
(\mathrm{ft} / \mathrm{d})\end{array}$ & & $>50$ & $25-50$ & $10-25$ & $<10$ & $\mathrm{~T}$ \\
\hline 10.2 & -- & 3.13 & Kaolinite & Chlorite & $\begin{array}{l}\text { I11ite } \\
\text { Smectite }\end{array}$ & Quartz & Gibbsite \\
\hline 56.7 & -- & .37 & Smect ite & -- & Kaolinite & $\begin{array}{l}\text { Illite } \\
\text { Quartz }\end{array}$ & -- \\
\hline 24.4 & -- & 2.0 & Smectite & -- & Kaolinite & Quartz & -- \\
\hline 10.8 & -- & 3.4 & $\begin{array}{l}\text { Smectite/ } \\
\text { Chlorite }\end{array}$ & -- & Kaolinite & Quartz & Illite \\
\hline 53.9 & -- & -- & -- & -- & -- & -- & -- \\
\hline 31.2 & -- & .99 & $\begin{array}{l}\text { Smectite } \\
\text { (some } \\
\text { chlorite) }\end{array}$ & -- & Kaolinite & Quartz & Illite \\
\hline 73.7 & -- & -- & -- & -- & -- & -- & -- \\
\hline \multicolumn{5}{|l|}{ estimated } & Kaolinite & Illite & -- \\
\hline & 22.7 & -- & -- & -- & -- & -- & -- \\
\hline & 42.5 & -- & -- & -- & -- & -- & -- \\
\hline
\end{tabular}

site is presented in figure 8. Water in the surficial aquifer moves downgradient from areas of high water table to areas of low altitude. In the vicinity of the plant site, flow is to the southwest and southeast.

The May 1984 potentiometric surface of the Upper Floridan aquifer was reported to be about 5 feet above sea level in the vicinity of the Pinellas Plant (Barr and Shiner, 1984) and is presented in figure 9. The September 1984 potentiometric surface of the Upper Floridan aquifer (fig. 10) was reported by Barr (1984) to be between 5 and 10 feet above sea level. The May and September levels reflect the normal annual low and high water levels, respectively. Comparison of the water-table map (fig. 8) and the potentiometric surface maps (figs. 9 and 10) indicates a general downward movement of water from the surficial aquifer to the Upper Floridan aquifer in the vicinity of the plant. 
EXPLANATION

$\mathcal{N}$
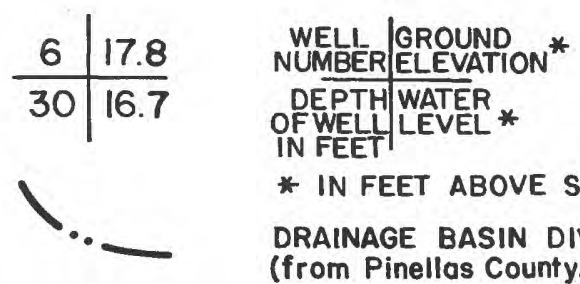

* in feet above sea level

DRAINAGE BASIN DIVIDE

(from Pinellas County, 1983)

A Stage measurement site

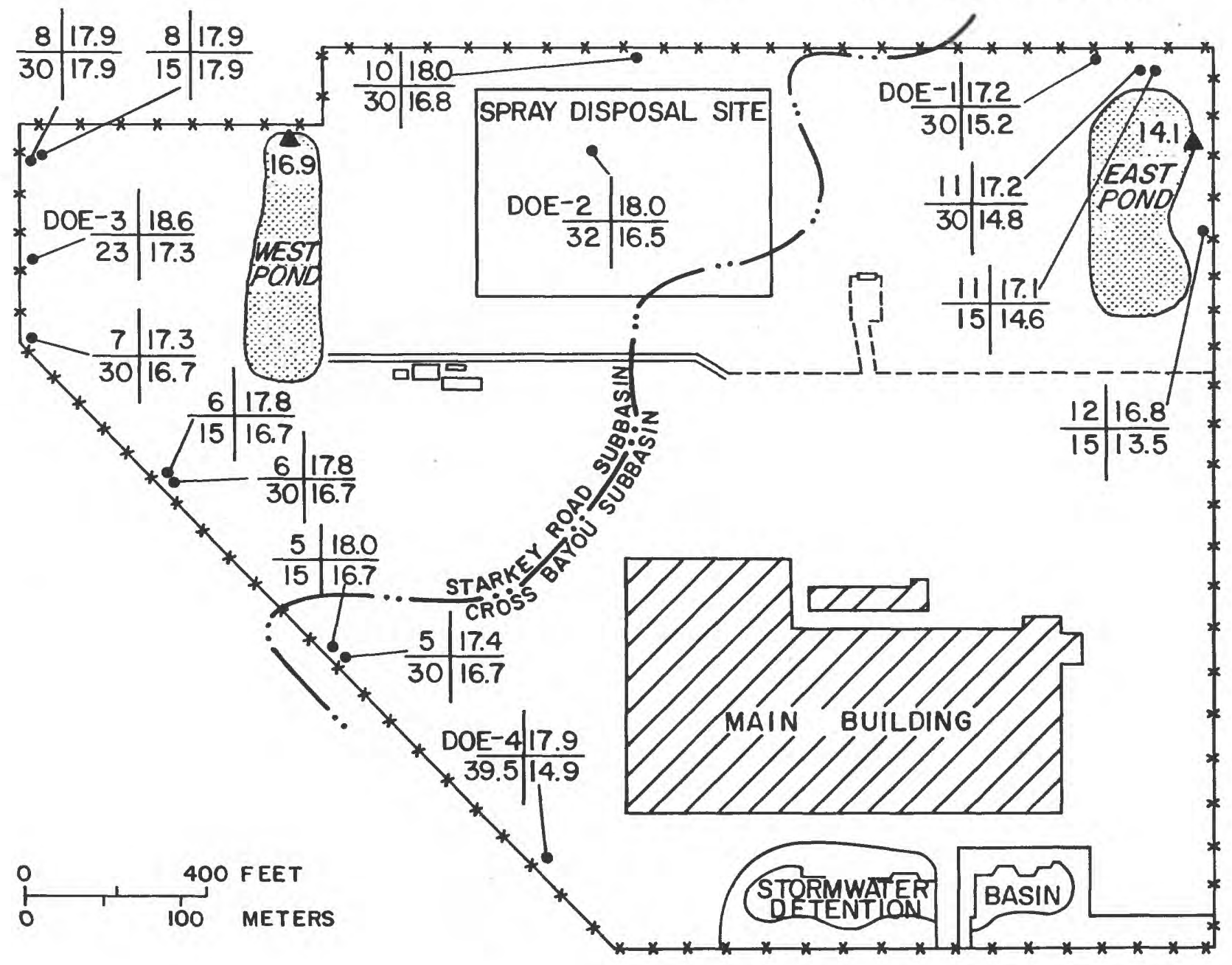

Figure 7.--Water levels, ground elevations, and depth of monitoring wells at the Pinellas Plant. 


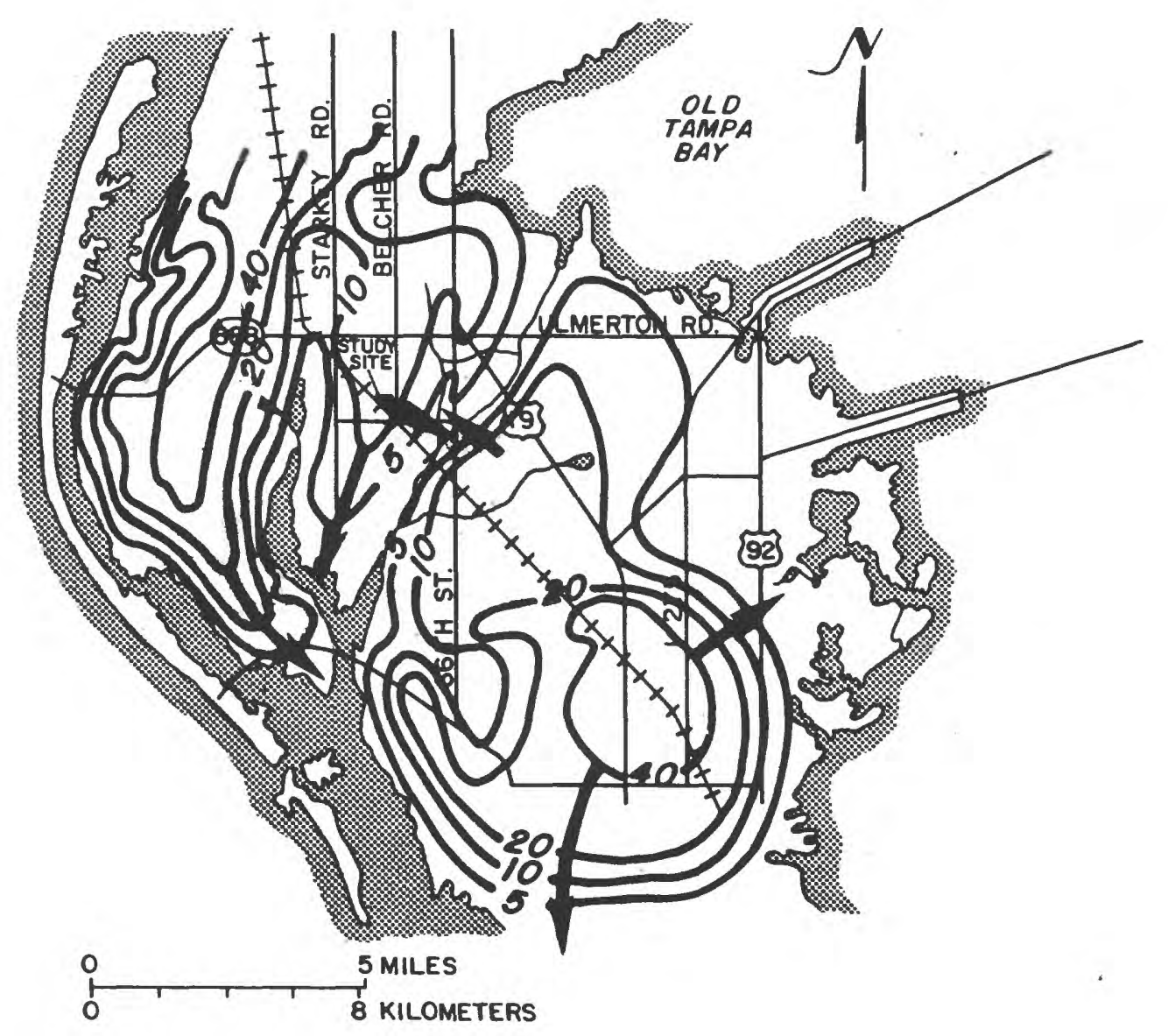

EXPLANATION

20_ WATER-TABLE CONTOUR BHOWG ALTITUDE OF
WATER TABLE IN FEET ABOVE SEA LEVEL

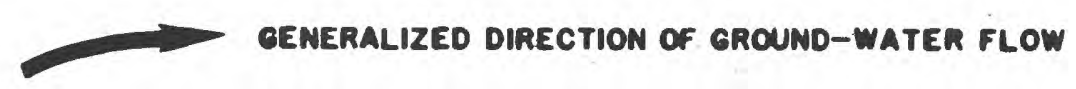

Figure 8.--Regional configuration of the water table in the surficial aquifer and direction of ground-water movement in mid-Pinellas County, May 1982 (modified from Causseaux, 1985). 


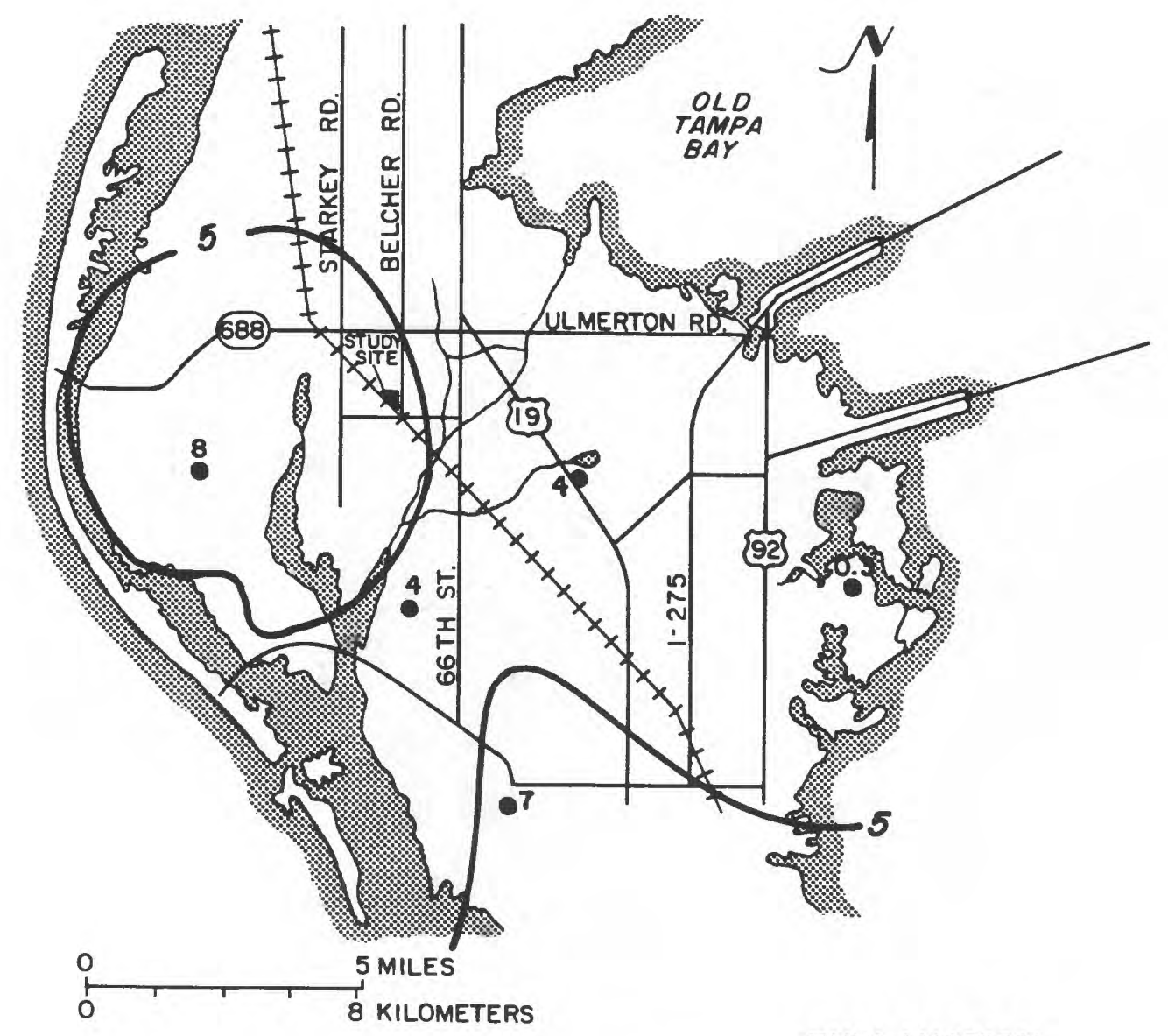

\section{EXPLANATION}

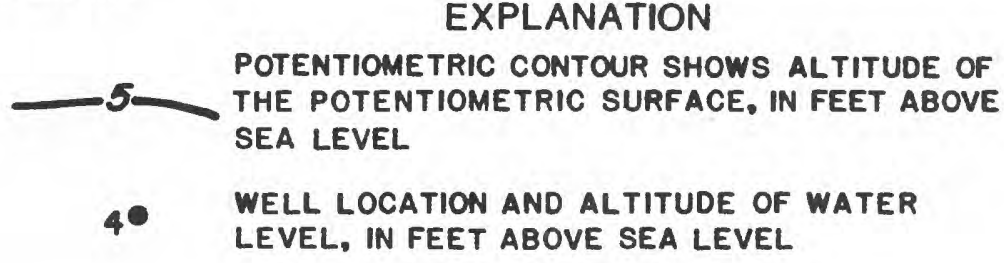

Figure 9.--Potentiometric surface of the Upper Floridan aquifer in mid-Pinellas County, May 1984 (modified from Barr and Schiner, 1984). 


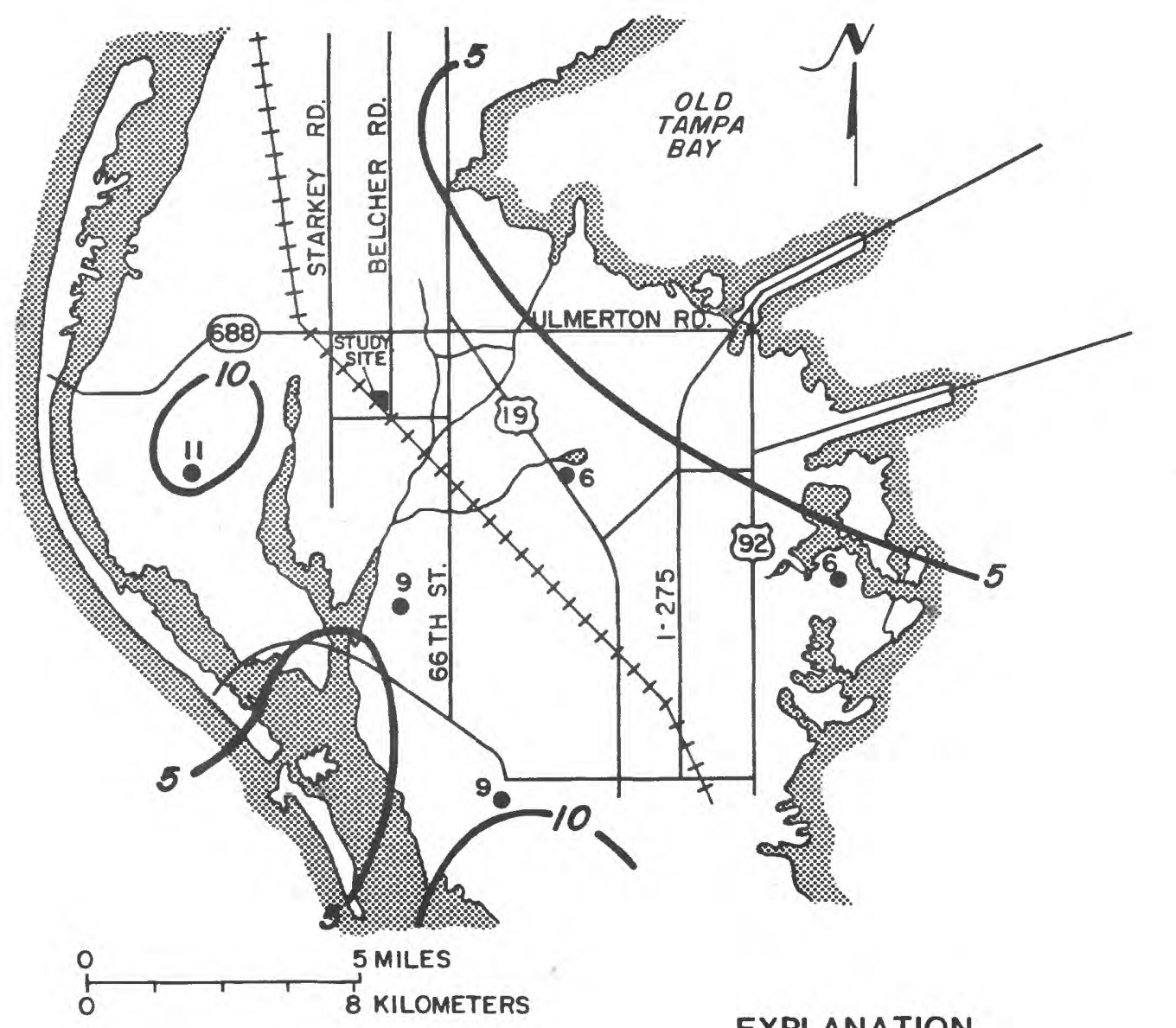

EXPLANATION

POTENTIOMETRIC CONTOUR SHOWS ALTITUDE OF THE POTENTIOMETRIC SURFACE, IN FEET ABOVE SEA LEVEL. CONTOUR INTERVAL 5 FEET

II WELL LOCATION AND ALTITUDE OF WATER - LEVEL, IN FEET ABOVE SEA LEVEL

Figure 10.--Potentiometric surface of the Upper Floridan aquifer in mid-Pinellas County, September 1984 (modified from Barr and Schiner, 1984). 
Table 4.--Hydraulic conductivities for the surficial aquifer in Pinellas and Hillsborough Counties and at the Pinellas Plant

\begin{tabular}{llc}
\hline Site & \multicolumn{1}{c}{$\begin{array}{c}\text { Hydraulic conductivity } \\
\text { (ft/d) }\end{array}$} \\
\hline Pinellas Plant - Horizontal \\
Hills borough and Pinellas Counties - & $0.2-73.7$ & $22.7-42.5$ \\
\hline I/ Hickey (1982, p. 8).
\end{tabular}

WATER QUALITY

Ground-water samples from wells DOE-1 through DOE-4 and surface-water samples from the east and west ponds (fig. 5) were collected and analyzed for priority pollutants, total organic carbon, herbicides, insecticides, trace metals, nutrients, and major constituents. Specific conductance and $\mathrm{pH}$ were measured in the field. Bottom materials from the east and west ponds were analyzed for all the above constituents except $\mathrm{pH}$, specific conductance, and major constituents. Methods used for collecting the water and bottom-material samples were according to Wood (1976) and Ehlke and others (1977). The samples were analyzed in U.S. Geological Survey laboratories according to methods of Brown and Goerlitz (1972), Skougstad and others (1972), Wood (1976), and the U.S. Environmental Protection Agency (1982). The Geological Survey laboratories operate under a quality assurance program that assures the quality of analytical data for water and fluvial sediment (Friedman and Erdman, 1982).

Results of laboratory analysis of the water and bottom materials are presented in Supplements 2 through 8. Values preceded by a less than $(<)$ symbol indicate that detectable amounts were not found and are reported as less than the minimum detection limits of the analytical technique. The results are presented in relation to analytical detection limits, reported background water quality, and criteria of the U.S. Environmental Protection Agency (1976). There are no standards for soil or bottom material (Dean Jackman, Florida Department of Environmental Regulation, oral commun., 1984). The following is a summary of the results of analyses of the water and bottom material.

\section{Field Measurements, Major Constituents, and Nutrients}

Analytical results for field measurements, major constituents, and nutrients for water and bottom-material samples are presented in Supplements 2 and 3. Tables 5 and 6 compare the observed water quality reported for DOE-1 through DOE-4 and the east and west ponds, respectively, with observed ranges 
Table 5.--Selected water-quality constituents and physical characteristics for ground water from an unaltered site in central Pinellas County and wells at the Pinellas Plant

[ $\mu \mathrm{S} / \mathrm{cm}$, microsiemens per centimeter; mg/L, milligrams per liter]

\begin{tabular}{|c|c|c|c|c|c|}
\hline $\begin{array}{l}\text { Constituents and } \\
\text { physical properties }\end{array}$ & $\begin{array}{l}\text { Background }{ }^{1 /} \\
\text { ground-water } \\
\text { range }\end{array}$ & DOE-1 & DOE-2 & DOE-3 & DOE -4 \\
\hline Specific conductance, & & & & & \\
\hline$\mu \mathrm{S} / \mathrm{cm}$ & $800-2,310$ & 1,360 & 1,040 & 960 & 1,340 \\
\hline $\mathrm{pH}$, units - & $6.1-7.7$ & 6.6 & 6.8 & 6.7 & 6.7 \\
\hline $\begin{array}{l}\text { Nitrogen, organic } \\
\text { (total), } \mathrm{mg} / \mathrm{L}\end{array}$ & $0.88-3.4$ & 2.81 & 1.28 & 1.55 & 1.30 \\
\hline $\begin{array}{l}\text { Nitrogen, ammonia } \\
\text { (total), } \mathrm{mg} / \mathrm{L}\end{array}$ & $0.08-3.4$ & 0.39 & 0.52 & 0.45 & 0.40 \\
\hline $\begin{array}{l}\text { Nitrogen, nitrite } \\
\text { (total), mg/L }\end{array}$ & $0.00-0.03$ & 0.04 & 0.01 & 0.01 & 0.02 \\
\hline $\begin{aligned} \text { Nitrogen, } & \text { nitrate } \\
(\text { tota } 1), & \mathrm{mg} / \mathrm{L}\end{aligned}$ & $0.00-0.02$ & 0.06 & 0.09 & 0.09 & 0.08 \\
\hline $\begin{array}{l}\text { Calcium, dissolved, } \\
\mathrm{mg} / \mathrm{L}\end{array}$ & $94-250$ & 130 & 140 & 130 & 160 \\
\hline $\begin{array}{l}\text { Magnesium, dissolved, } \\
\mathrm{mg} / \mathrm{L}\end{array}$ & $3.6-28$ & 13 & 13 & 6.8 & 10 \\
\hline $\begin{array}{l}\text { Sodium, dissolved, } \\
\text { mg/L }\end{array}$ & $34-280$ & 230 & 86 & 90 & 130 \\
\hline $\begin{array}{l}\text { Potassium, dissolved, } \\
\text { mg/L }\end{array}$ & $24-190$ & 2 & 3.4 & 0.8 & 2.3 \\
\hline $\begin{array}{l}\text { Chloride, dissolved, } \\
\mathrm{mg} / \mathrm{L}\end{array}$ & $63-439$ & 180 & 150 & 70 & 200 \\
\hline
\end{tabular}

1/ Modified from Fernandez and Barr (1984, p. 23).

for selected constituents from an unaltered reference site. The unaltered reference site used for comparison is about 5 miles east of the Pinellas Plant (fig. 1) and was reported by Fernandez and Barr (1984) as being representative of water from the surficial aquifer and surface water in undeveloped areas of central Pinellas County. The nitrogen concentrations for nitrate and organic nitrogen for samples from wells DOE-1 through DOE-4 and the east and west ponds were computed by subtracting the concentrations for $\mathrm{NO}_{2}$ as $\mathrm{N}$ and $\mathrm{NH}_{4}$ as $\mathrm{N}$ from the concentrations for $\mathrm{NO}_{2}+\mathrm{NO}_{3}$ as $\mathrm{N}$ and $\mathrm{NH}_{4}+$ organic $\mathbb{N}$ as $\mathrm{N}$, respectively. Concentrations of all constituents and physical properties listed in table 5 are within the reported range for background data except for nitrite- and nitratenitrogen concentrations, which were slightly higher, and potassium, which was appreciably lower. The comparison for surface waters (table 6) indicates that concentrations for many constituents in water from the east and west ponds exceed the concentrations of the reference surface water. Concentrations of calcium and magnesium, however, were lower than reference site levels. 
Table 6.--Selected water-quality constituents and physical characteristics for an unaltered site in central Pinellas County and ponds at the Pinellas plant

[ $\mu \mathrm{S} / \mathrm{cm}$, microsiemens per centimeter; mg/L, milligrams per liter]

\begin{tabular}{|c|c|c|c|}
\hline $\begin{array}{l}\text { Constituents and } \\
\text { physical properties }\end{array}$ & $\begin{array}{l}\text { Backg round } 1 / \\
\text { surface-water } \\
\text { range }\end{array}$ & $\begin{array}{l}\text { East } \\
\text { pond }\end{array}$ & $\begin{array}{l}\text { West } \\
\text { pond }\end{array}$ \\
\hline Specific conductance, $\mu \mathrm{S} / \mathrm{cm}$ & $398-860$ & 6,700 & 780 \\
\hline pH, units - & $6.9-8.5$ & 8.5 & 9.0 \\
\hline Nitrogen, organic (total), mg/L - & $0.67-0.88$ & 2.89 & 3.29 \\
\hline Nitrogen, ammonia (total), mg/L -- & $0.00-0.15$ & 0.01 & 0.01 \\
\hline Nitrogen, nitrite (total), mg/L --_--- & $0.00-0.01$ & 0.01 & 0.02 \\
\hline Nitrogen, nitrate (total), mg/L - & $0.00-0.07$ & 0.09 & 0.08 \\
\hline Calcium, dissolved, mg/L - & $44-78$ & 34 & 58 \\
\hline Magnesium, dissolved, mg/L -- & $6.7-17$ & 2.5 & 8.2 \\
\hline Sodium, dissolved, mg/L - & $30-100$ & 36 & 100 \\
\hline Potassium, dissolved, mg/L _- & $0.7-2.4$ & 1.5 & 4.2 \\
\hline Chloride, dissolved, mg/L _- & $44-150$ & 52 & 100 \\
\hline
\end{tabular}

I/ From Fernandez and Barr (1984, p. 24).

Trace Elements

Analytical results for concentrations of trace elements in the groundwater, surface-water, and bottom-material samples are presented in Supplement 4. Results for water samples indicate that concentrations, except for iron, are less than the analytical detection limits or are within U.S. Environmental Protection Agency (1976) criteria. Although total iron for wells DOE-1 through DOE-4 ranged from 2, 000 to $6,300 \mu \mathrm{g} / \mathrm{L}$ (micrograms per 1iter), far exceeding the criteria standards (p. 78) of $300 \mu \mathrm{g} / \mathrm{L}$, the reported values (Supplement 4) were within the observed range of 990 to $18,000 \mu \mathrm{g} / \mathrm{L}$ for the reference study site. The results of analyses for bottom materials given below indicate that the west pond has slightly greater concentrations of trace elements than the east pond.

\begin{tabular}{|c|c|c|}
\hline \multirow{2}{*}{ Constituent } & \multicolumn{2}{|c|}{$\begin{array}{l}\text { Concentration } \\
\text { (micrograms per gram) }\end{array}$} \\
\hline & East pond & West pond \\
\hline Chromium - & 350 & 670 \\
\hline 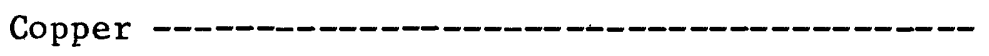 & 1,200 & 1,600 \\
\hline 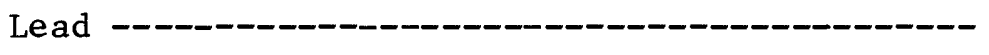 & 150 & 340 \\
\hline Mercury - - & 5.7 & 30 \\
\hline
\end{tabular}




\section{Total Organic Carbon}

The analytical results for total organic carbon for ground water, surface water, and bottom material are presented in table 7. The concentrations of total organic carbon for water samples ranged from 11,000 to $130,000 \mu \mathrm{g} / \mathrm{L}$. The concentrations of total organic carbon for bottom material for the east pond was $72 \mathrm{~g} / \mathrm{kg}$ (grams per kilogram).

Table 7.--Total organic carbon in ground-water, surface-water, and bottom-material samples at the Pinellas Plant

[Concentrations are in micrograms per 1iter, except as noted]

\begin{tabular}{cc} 
Site & $\begin{array}{c}\text { Total } \\
\text { organic carbon }\end{array}$ \\
\hline
\end{tabular}

Water samples:

$\begin{array}{lr}\text { DOE-1 } & 130,000 \\ \text { DOE-2 } & 56,000 \\ \text { DOE-4 } & \\ \text { East pond } & \\ \text { West pond } & \end{array}$

Bottom-material samples:

East pond - -

West pond -

1/ Grams per kilogram.

\section{Organic Priority Pollutants}

Ground-water, surface-water, and bottom-material samples were analyzed using gas chromatography/multispectral analysis (GC/MS) for determination of selected priority pollutants (acid extractables, base/neutrals, herbicides, insecticides, and purgeable compounds). These organic compounds are among those listed as priority pollutants in 40 CFR, Part 122, Appendix D, July 1, 1983, and in Section 307, (a) (1) 1977 Clean Water Act (33 U.S.C., 466 et seq.; Committee Print HR. 3199). Peaks in the chromatograph that did not pertain to the priority pollutants were identified, when possible, by comparison of the peaks with mass spectra stored in the National Bureau of Standards Library and were classified as nonpriority pollutants. All compounds analyzed met identification criteria (U.S. Environmental Protection Agency, 1982).

For the purpose of this summary, the priority pollutants are presented under two classifications: (1) herbicides and insecticides and (2) polynuclear aromatic hydrocarbons (PAH's) and other hydrocarbons. Analytical 
results for herbicides and insecticides for ground water, surface water, and bottom material are presented in Supplement 5. Neither herbicides nor insecticides were detected in water samples; if present, the concentrations in the water samples were less than detection limits.

Results of analyses of bottom material indicate that four insecticides-chlordane, $28 \mu \mathrm{g} / \mathrm{kg}$ (micrograms per kilogram); DDD, $19 \mu \mathrm{g} / \mathrm{kg}$; DDE, $5.5 \mu \mathrm{g} / \mathrm{kg}$; and ploychlorinated biphenyls ( $\left.P C C^{\prime} \mathrm{s}\right), 340 \mu \mathrm{g} / \mathrm{kg}$--were found in material from the east pond, and three insecticides-chlordane, $3 \mu \mathrm{g} / \mathrm{kg}$; dieldrin, $0.2 \mu \mathrm{g} / \mathrm{kg}$; and $P C B^{\prime} \mathrm{s}, 230 \mu \mathrm{g} / \mathrm{kg}$--were found in material from the west pond. Herbicides were not detected in bottom-material samples; if present, the concentrations for bottom-material samples were less than the detection limits.

The analytical results for $\mathrm{PAH}^{\prime} \mathrm{s}$ and other hydrocarbons for water samples are presented in Supplement 6. No PAH's or other hydrocarbons were found; if present, the concentrations for water samples were less than detection limits. Analytical results from bottom-material samples are presented in Supplement 7. Analytical results indicate that 12 compounds, $11 \mathrm{PAH}$ 's and a phthalate, were found in the east pond. Only one compound, a phthalate, was found in the material from the west pond. If present, concentrations of other compounds in bottom-material samples from the east and west ponds were less than detection limits. The following is the concentration and reported hazards for each identified compound in the bottom material of the east pond:

1. Anthracene: $220 \mu \mathrm{g} / \mathrm{kg}--\mathrm{A}$ PAH derived from coal tar (Merck and Co., 1976, p. 93). It is reported to be a recognized carcinogen of skin, hands, forearms, and scrotum and, experimentally, of the bladder (Sax, 1979, p. 382).

2. Bis(2-ethylhexyl)phthalate: $290 \mathrm{\mu g} / \mathrm{kg}--\mathrm{It}$ is a phthalate ester used as a plasticizer for many resins and elastomers (Hawley, 1981, p. 349). Its toxicity is low to nonexistent; however, on a chronic basis, it is a teratogen (Sax, 1979, p. 479).

3. Benzo(a)anthracene: $1,500 \mu \mathrm{g} / \mathrm{kg}--\mathrm{A} \mathrm{PAH}$, it is a derivative from coal tar (Fieser and Fieser, 1961, p. 641). It is reported to be highly toxic and an experimental carcinogen (Buckingham, 1982, p. 528).

4. Benzo(b)fluoranthene: $750 \mu \mathrm{g} / \mathrm{kg}--\mathrm{A}$ PAH derived from coal tar (Fieser and Fieser, 1961, p. 641). It is reported to be an experimental carcinogen (Sax, 1979, p. 406).

5. Benzo(k)fluoranthene: $1,200 \mu \mathrm{g} / \mathrm{kg}--\mathrm{A}$ PAH derived from coal tar (Fieser and Fieser, 1961). It is an experimental carcinogen and neoplasmic to mice via dermal and subcutaneous routes (Sax, 1979, p. 406).

6. Benzo(a)pyrene: $890 \mu \mathrm{g} / \mathrm{kg}--\mathrm{A}$ PAH that occurs in coal tar (Merck and Co., 1976, p. 144). It is.reported by $\operatorname{Sax}(1979$, p. 407) that exposure can cause death or permanent injury; it requires special handling.

7. Benzo(g,h, $\mathrm{i})$ perylene: $410 \mu \mathrm{g} / \mathrm{kg}--\mathrm{A}$ PAH that occurs in coal tar. It is a carcinogen (Buckingham, 1982, p. 567). Sax (1979, p. 407) reports it to be an experimental carcinogen.

8. Chrysene: 2,300 $\mu \mathrm{g} / \mathrm{kg}--\mathrm{A}$ PAH that occurs in coal tar (Merck and Co., 1976, p. 292). It is capable of causing death or permanent injury due to exposure during normal use, it is an experimental neoplasmic agent, 
and it has been classified as a carcinogen by the International Agency for Research of Cancer (Sax, 1979, p. 506). It is considered to be a suspect human carcinogen because known human carcinogens contain it (Sax, 1981, p. 342).

9. Fluoranthene: $5,500 \mu \mathrm{g} / \mathrm{kg}--\mathrm{A}$ PAH derived from coal tar. It is moderately toxic (Sax, 1979, p. 688) and it is reported to be a potent carcinogen (Sittig, 1981, p. 335).

10. Indeno(1,2,3-cd)pyrene: $420 \mu \mathrm{g} / \mathrm{kg}--\mathrm{A}$ PAH derived from coal tar. Although there are not any epidemiological case studies stating that it is a human carcinogen, this material is a suspect human carcinogen because it may be a constituent of a known carcinogen such as coal tar (Sax, 1981, p. 381).

11. Phenanthrene: $1,600 \mu \mathrm{g} / \mathrm{kg}--\mathrm{A}$ PAH that occurs in coal tar (Merck and Co., 1976, p. 934). It is a skin sensitizer and an experimental carcinogen via dermal route (Sax, 1979, p. 896).

12. Pyrene: $4,600 \mu \mathrm{g} / \mathrm{kg}--\mathrm{A}$ PAH that is derived from coal tar. Hawley (1981, p. 872) reports that pyrene is a carcinogenic agent that is absorbed by skin. Sax (1979, p. 947), however, reports it to be an agent that, although it causes neoplasms, the neoplasms are nonmetastisizing.

The following priority pollutant was found in the bottom material of the west pond:

1. Bis(2-ethylhexyl)phthalate: $1,900 \mu \mathrm{g} / \mathrm{kg}$ (see discussion of compound under number 2 for the east pond).

\section{Organic Nonpriority Pollutants}

Analytical results for nonpriority pollutants in water and bottom-material samples are presented in Supplement 8. Forty-one peaks were observed for the water samples, of which 13 were identified. Most peaks that were identified as contaminants were also present in the reagent/glassware blank. Ten peaks, nine in a sample from the east pond and one in a sample from the west pond, were observed and identified in bottom-material samples. These compounds were identified by comparison with mass spectra stored in the National Bureau of Standards Library.

\section{SUMMARY}

The Pinellas Plant of the U.S. Department of Energy has been in operation since about 1956. The facility is operated by the Neutron Devices Department of the General Electric Company. The plant produces four types of liquid waste:

(1) chemical, (2) liquids potentially containing tritium, (3) sanitary, and (4) industrial. The chemical waste is separated for special handling. The liquids containing tritium are treated onsite, combined with other waste, and released to the Pinellas County sewage-collection system. Prior to September 1972, treated industrial wastewater and, prior to October 1973, treated sanitary waste were diverted offsite by way of a series of drainage ditches into 
the Cross Bayou Canal. Prior to December 1982, the wastes, except for chemical wastes, were treated and disposed of at a 10-acre spray-irrigation plot within the plant site. Two ponds that have a combined capacity of approximately 5.84 Mgal were used, together with the spray-irrigation system, to treat and dispose of the combined industrial and sanitary waste.

To determine whether there were any variations in the ground electrical conductivity and in the ground-water system due to spray irrigation, a preliminary electromagnetic survey was conducted on the study area, including the spray site and the area around the ponds. Apparent ground conductivities for the study area ranged from 18 to $94 \mathrm{mmhos} / \mathrm{m}$, except for isolated areas where readings were greater than $100 \mathrm{mmhos} / \mathrm{m}$. The readings greater than $100 \mathrm{mmhos} / \mathrm{m}$ may indicate the existence of underground conductors, such as pipes, cables, and metal drums. Readings in the spray disposal area ranged from 22 to 27 mmhos $/ \mathrm{m}$, whereas readings in the rest of the area between the ponds ranged from 20 to $94 \mathrm{mmhos} / \mathrm{m}$. Preliminary findings indicate that the spray disposal area does not differ from the rest of the study area. An area west of the west pond was found to have ground conductivities ranging from 18 to $30 \mathrm{mmhos} / \mathrm{m}$. This area could be used in future studies as the baseline ground conductivity for the area.

Four test wells drilled into the surficial aquifer range in depth from 23 to 39.5 feet and have screen lengths of 5 feet. Ten core samples from well DOE-4 were analyzed for physical characteristics. Particle sizes ranged from 69.7 to 98.1 percent sand and gravel, 0 to 3.4 percent silt, and 1.9 to 26.9 percent clay. The clay fraction contained kaolinite, smectite, chlorite, quartz, gibbsite, and illite. The total porosity ranged from 31.9 to 52.8 percent. Vertical hydraulic conductivity was between 10.2 and $73.7 \mathrm{ft} / \mathrm{d}$ at $22^{\circ} \mathrm{C}$, with the exception of one core where the hydraulic conductivity was estimated to be about $0.2 \mathrm{ft} / \mathrm{d}$. The cation exchange capacity ranged from 0.37 to 11.9 meq/100 grams in the core samples. The horizontal hydraulic conductivities for two core samples obtained from a depth of 8.0 feet below land surface were 22.7 and $42.5 \mathrm{ft} / \mathrm{d}$ at $22^{\circ} \mathrm{C}$.

Stratigraphic units that underlie the site, in descending order of deposition, are the (1) undifferentiated surficial deposits of Pleistocene age; (2) the Hawthorn Formation of middle Miocene age; and (3) the Tampa Limestone of early Miocene age. The three hydrogeologic units that underlie the area are (1) the surficial aquifer, (2) the upper confining bed of the Upper Floridan aquifer, and (3) the Upper Floridan aquifer.

The four test wells and all existing test wells were incorporated into a monitoring network. Water levels in the surficial aquifer ranged from 13.8 to 17.9 feet above sea level, and the levels of the east and west ponds were 14.1 and 16.9 feet above sea level, respectively. The direction of ground-water movement is to the southwest and southeast.

The results of water-quality analyses indicate that concentrations of major constituents and nutrients are within the reported range for background water quality, except for nitrite- and nitrate-nitrogen and potassium. Concentrations of these constituents in water from the east and west ponds exceed the ranges for background surface water. 
The results of analyses for trace metals in the ground-water and surfacewater samples indicate that the concentrations are less than detection limits or within criteria limits of the U.S. Environmental Protection Agency. Bottom material from the west pond has higher concentrations of trace metals than those from the east pond.

Herbicide and insecticide concentrations, if present in ground-water and surface-water samples, were less than detection limits. Concentrations of four insecticides in bottom material from the east pond and concentrations of three insecticides in bottom material from the west pond were above detection limits.

Concentrations of organic priority pollutants and total organic carbon in ground-water and surface-water samples were less than the detection limits. Twelve organic priority pollutants were found in bottom material of the east pond and one in bottom material of the west pond. Most of the priority po1lutants in the east pond are coal tar derivatives. 


\section{REFERENCES}

Applegate, C. H., 1983, Environmental assessment for the United States Department of Energy, Pinellas Plant, St. Petersburg, Florida: March 1983 (unpub1ished report).

Barr, G. L., 1984, Potentiometric surface of the Upper Floridan aquifer, Southwest Florida Water Management District, September 1984: U.S. Geological Survey Open-File Report 84-812, 1 sheet.

Barr, G. L., and Schiner, G. R., 1984, Potentionetric surface of the Floridan aquifer, Southwest Florida Water Management District, May 1984: U.S. Geological Survey Open-File Report 84-620, 1 sheet.

Brown, Eugene, and Goerlitz, D. F., 1972, Methods for analysis of organic substances in water: U.S. Geological Survey Techniques of Water-Resources Investigations, Book 5, Chapter A3, 40 p.

Buckingham, J. (ed.), 1982, Dictionary of organic compounds (5th edition): New York, Chapman and Ha11, v. 1-5, 5,769 p.

Buono, Anthony, and Rutledge, A. T., 1979, Configuration of the top of the Floridan aquifer, Southwest Florida Water Management District: U.S. Geological Survey Water-Resources Investigations Open-File Report 78-34, 1 sheet.

Buono, Anthony, Spechler, R. M., Barr, G. L., and Wolansky, R. M., 1979, Generalized thickness of the confining bed overlying the Floridan aquifer, Southwest Florida Water Management District: U.S. Geological Survey Water-Resources Investigations Open-File Report 79-1171, 1 sheet.

Causseaux, K. W., 1985, The surficial aquifer in Pinellas County, Florida: U.S. Geological Survey Water-Resources Investigations Report 84-4289 (in press).

Ehlke, T. A., Irwin, G. A., Lium, B. W., and Slack, K. V., 1977, Methods for collection and analysis of aquatic, biological and microbiological samples: U.S. Geological Survey Techniques of Water-Resources Investigations, Book 5, Chapter A4, $332 \mathrm{p}$.

Environmental Associates, Inc., 1980, Pinellas Plant waste management study: Consultant's report prepared for the U.S. Department of Energy.

Federal Emergency Management Agency, 1983a, Flood insurance rate map, Pinellas County: Community-Pane1 no. 125139 0138c.

---- 1983b, Flood insurance rate map, Pinellas County: Community-Panel no. $1251390201 c$.

---- 1983c, Flood insurance rate map, Pinellas County: Community-Panel no. $1251390182 \mathrm{c}$.

--- 1983d, Flood insurance rate map, Pinellas County: Community-Panel no. $1251390119 c$.

Fernandez, Mario, Jr., and Barr, G. L., 1984, Chemical quality of landfill leachate in treatment ponds and migration of leachate in the surficial aquifer, Pinellas County, Florida: U.S. Geological Survey Water-Resources Investigations Report 83-4193, $52 \mathrm{p}$. 
Fieser, L. F., and Fieser, M., 1961, Advanced organic chemistry: New York, Reinhold Publishing Corporation, 1, 158 p.

Freeze, R. A., and Cherry, J. A., 1979, Groundwater: Englewood Cliffs, New Jersey, Prentiss Hall, 604 p.

Friedman, L. C., and Erdman, D. E., 1982, Quality assurance practices for the chemical and biological analyses of water and surficial sediments: U.S. Geological Survey Techniques of Water-Resources Investigations, Book 5, Chapter A6, 181 p.

Geonics Limited, 1984, Operating manual for EM31-D non-contacting terrain conductivity meter: Ontario, Canada, $60 \mathrm{p}$.

Hamilton, W. L., 1926, Aerial photographic map, Pinellas County, Florida: New York, Hamilton Maxwe1l, Inc.

Hawley, G. G., 1981, The condensed chemical dictionary (10th edition, revised): New York, Van Nostrand Reinhold Company, 1,135 p.

Heath, R. C., and Smith, P. C., 1954, Ground-water resources of Pinellas County, Florida: Florida Geological Survey Report of Investigations 12, $139 \mathrm{p}$.

Hickey, J. J., 1982, Hydrogeology and results of injection tests at wasteinjection test sites in Pinellas County, Florida: U.S. Geological Survey Water-Supply Paper 2183, 42 p.

Hoisel-Terpening and Associates, 1979, Pavement and drainage study for General Electric Company Neutron Devices Department located at United States Department of Energy's Pinellas Plant, Florida: Consultant's report prepared for the U.S. Department of Energy.

Merck and Co., 1976, The Merck index and encyclopedia of chemical and drugs ( 9 th edition), Martha Windholz, ed.: Rahway, New Jersey, Merck and Co., $10,490 \mathrm{p}$.

Pinellas County, 1983, Stormwater management plan: In the files of the Department of Public Works and Utilities, Pinellas County, Florida.

Sax, N. I., 1979, Dangerous properties of industrial materials (5th edition): New York, Van Nostrand Reinhold Company, 1,118 p.

---- 1981, Cancer causing chemicals: New York, Van Nostrand Reinhold Company, $466 \mathrm{p}$.

Sinclair, W. C., 1982, Sinkhole development resulting from ground-water withdrawal in the Tampa area, Florida: U.S. Geological Survey Water-Resources Investigations $81-50,19 \mathrm{p}$.

Sittig, M., 1981, Handbook of toxic and hazardous chemicals: New Jersey, Noyes Publications, 729 p.

Skougstad, W. S., Fishman, M. J., Friedman, L. C., Erdman, D. E., and Duncan, S. S. (eds.), 1972, Methods for the determination of inorganic substances in water and fluvial sediments: U.S. Geological Survey Techniques of Wa ter-Resources Investigations, Book 5, Chapter A1, 626 p.

Southwest Florida Water Management District, 1984a, List of wells requiring withdrawal permits: Report no. 41-099 in the computer files of the Southwest Florida Water Management District.

1984b, List of wells not requiring withdrawal permits: Report no. 42090 in the computer files of the Southwest Florida Water Management District. 
Stewart, M. T., 1981, Evaluation of electromagnetic terrain conductivity measurements for detection and mapping of saltwater interfaces in coastal aquifers: Tampa, Florida, Geology Department, University of South Florida.

U.S. Department of Agriculture, 1972, Soil survey of Pinellas County, Florida: Soil Conservation Service, 64 p., 33 plates.

U.S. Department of Commerce, 1984, Monthly normals of temperature, precipitation, and heating and cooling degree days, 1951-80, Florida: Asheville, N.C., National Oceanic and Atmospheric Administration, Environmental Data Service.

U.S. Department of Energy, 1981a, Requirements for radiation protection: U.S. Department of Energy Order 5480.1, Chapter X1, August 13, 1981.

---- 1981b, Pinellas Plant environmental monitoring report: GEPP-EM-654.

---- 1982, Pinellas P1ant environmental monitoring report: GEPP-EM-729 UC20e.

---- 1983, Pinellas Plant environmental monitoring report: GEPP-EM-806 UC20e.

U.S. Environmental Protection Agency, 1976, Quality criteria for water: EPA 440/9-76-004, 196 p.

1982, Methods for organic chemical analysis of municipal and industrial waste waters, Longbetter, J. F., and Lichtenberg, J. J., eds.: EPA-600/4$82-057$.

Wood, W. W., 1976, Guidelines for collection and field analyses of ground-water samples for selected unstable constituents: U.S. Geological Survey

Techniques of Water-Resources Investigations, Book 1, Chapter D2, 24 p. 


\title{
SUPPLEMENT 1
}

Analysis by University of South Florida of 10 Core Samples From the Plant Site

\author{
UNIVERSITY OF SOUTH FLORIDA
}

TAMPA • ST. PETERSBURG - FORT MYERS - SARASOTA

DEPARTMENT OF GEOLOGY

TAMPA, FLORIDA 33620

813: $974-2236$

Mr. Mario Fernandez

U. S. Geological Survey, WRE

4710 Eisenhower Blvd.

Suite B5

Tampa, FI $\mathbf{3 3 6 1 4}$

Sept. 24,1984

Dear Mr. Fernandez

Enclosed are the results of the analyses that you requested on ten (10) core samples labeled with the prefix "D.O.E."

The permeability tests were run on a soil Test K-60s constant head permeater. The sample chamber has been bored to the outside diameter of the core tubes that you used. An appropriate length of core (about $7.2 \mathrm{~cm}$.) was cut from each core sample and $f i t t e d$ into the permeameter chamber and sealed to prevent leakage between the core liner and the inside wall of the chamber. After equilibrating the system, three discharge rate measurements were taken at 10 minute intervals. The results are consistent with previous results that we have obtained using this methodology. Generally, the results are near the ufper limit of permearibility estimated from corresponding grain size data. Other techniques might yield somewhat lower permeability coefficients.

The porosity (modified specific yield) was determined by calculating the volume of saturated material in the permeameter, extruding the material arid determining the we ight loss after over dryirg at $110 \mathrm{C}$. The weight lass in grams divided by the volume of sediment in cubic centimeters $(x 100)$ is reported as the modified specific yield.

Grain size analysis was conducted by wet sieving a portion of each sample through a b3u Eieve and oven drying of the >bau portion at $110 \mathrm{C}$. The \% sand regorted is, the percentage recovered by this technique. The < s3u fraction was collected and analyzed by pipette analysis as described in standard references such as Folk (1968), "Petrology of Sedimentary Rocks" and Griffiths (1967) "Scientific Method in Analysi of Sediments." The \% silt includes the size fractions between 63 and 3.90 . The $\%$ clay iricludes all partical sizes <3.9u.

The mineralogy of the (zu fraction (clay minerals) of the samples was determined by routine X-ray diffraction techniques including prefaration of "As Is" slides, glycolation with ethylene glycol, and heat treatments at 350 and $550 \mathrm{C}$. The relative abundarices were estimated based on peak areas arid are approximations only.

The cation exchange capacities were determined by sodium

THE UNIVERSITY OF SOUTH FLORIDA IS AN AFFIRMATIVE ACTION EQUAL OPPORTUNITY INSTITUTION 
saturation followed by multiple washings with D. I. Water and methanol to remove free sodium. The adsorbed sadium was then exchanged by misitiple washirgs with $1 \mathrm{~N}$ NH4 501 ution at a pH of 7 . The recovered sadium was analyzed by atomic absorption spectrometry.

If I can provide any further information concerning the test results or the analytical techniques, please do not hesitate to call on me.

\author{
Siricerly yours, \\ Eeckacel D. Dtion \\ Rictiard N. Strom \\ $A \equiv \equiv 0$ iate Professor
}




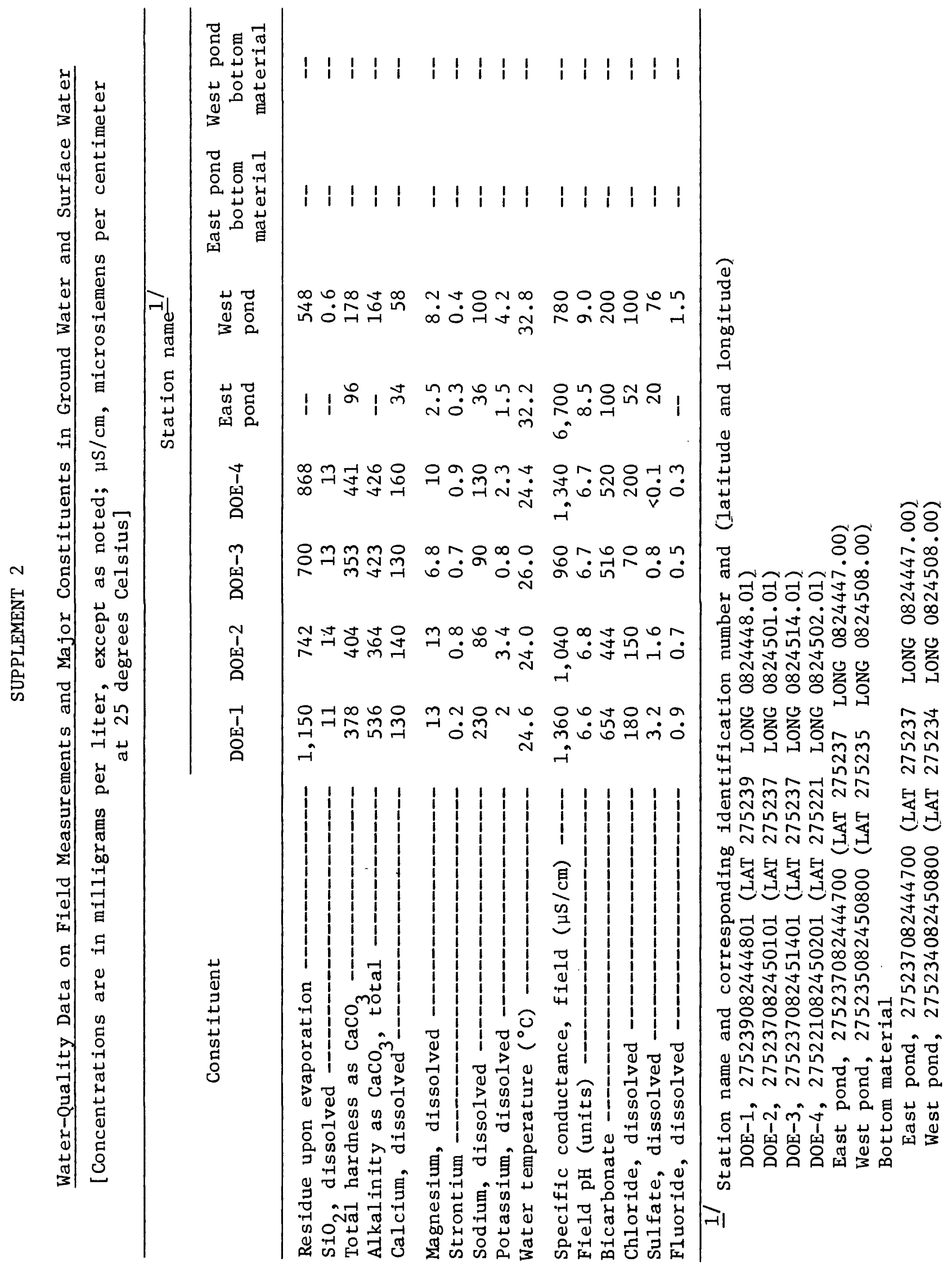




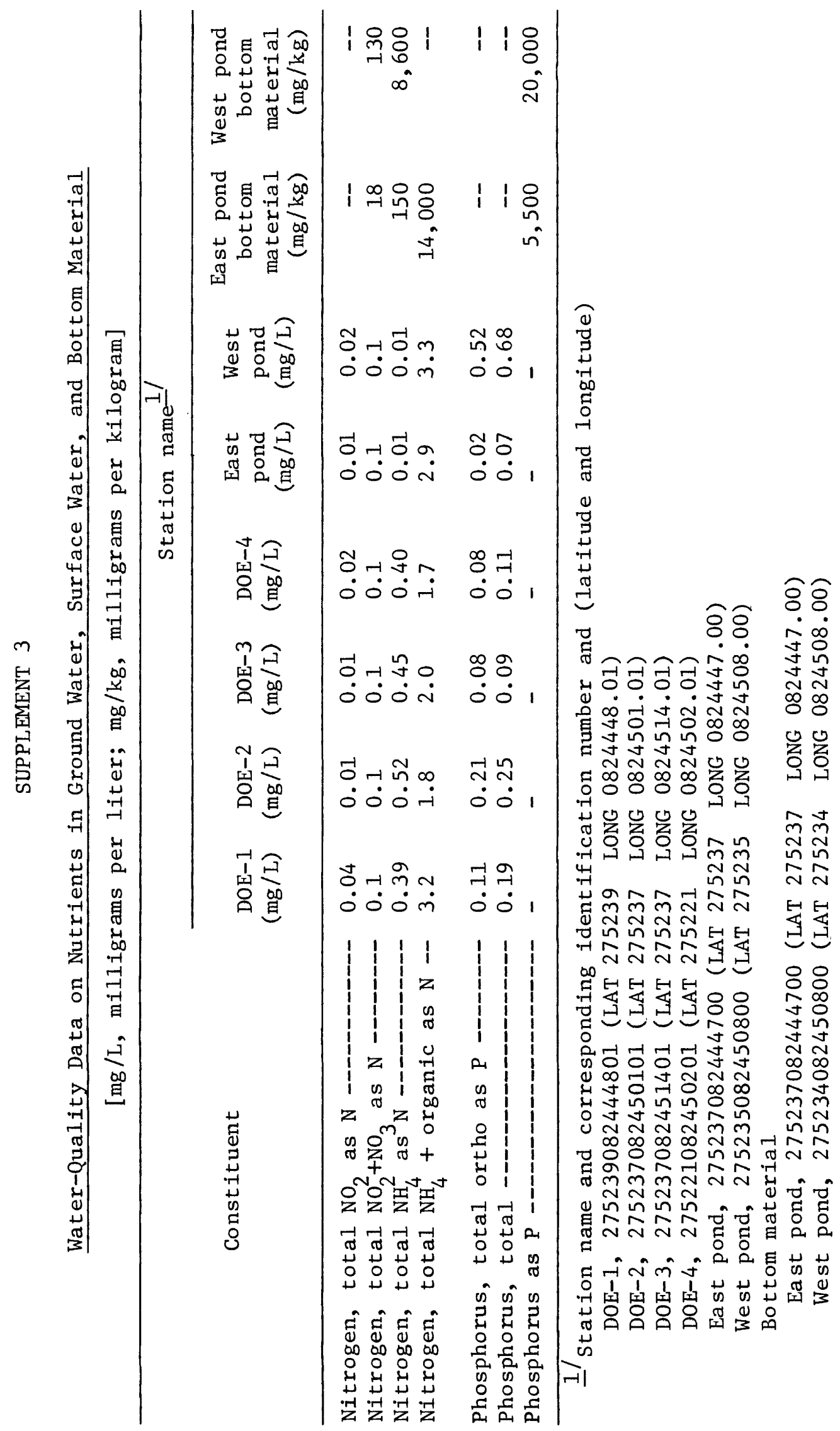




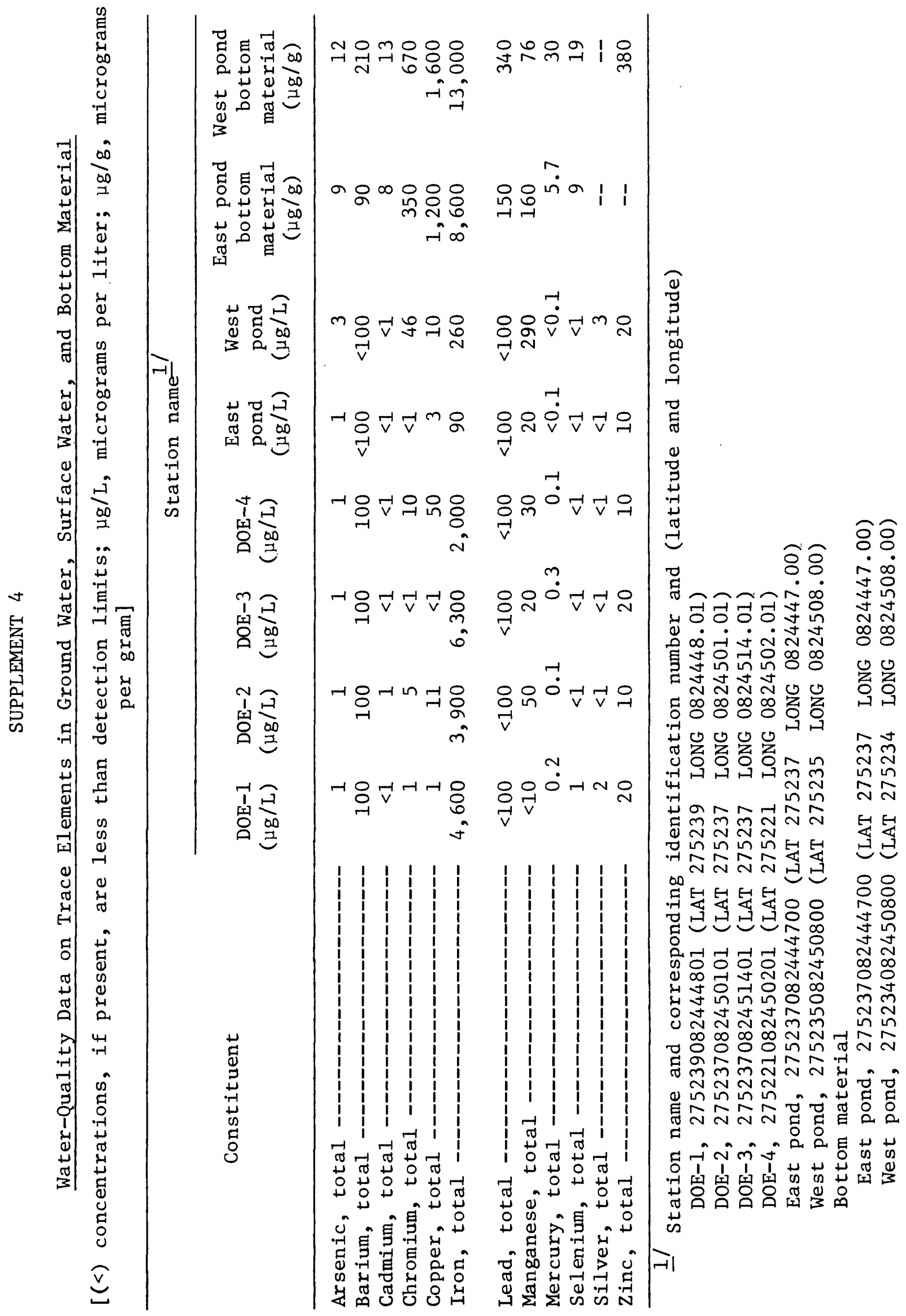




\section{SUPPLEMENT 5}

Water-Quality Data on Herbicides and Insecticides in Ground Water,

$$
\text { Surface Water, and Bottom Material }
$$

[ $(<)$ concentrations, if present, are less than detection limits; $\mu \mathrm{g} / \mathrm{L}$, micrograms per liter; $\mu \mathrm{g} / \mathrm{kg}$, micrograms per kilogram]

\begin{tabular}{|c|c|c|c|c|c|c|}
\hline \multirow[b]{2}{*}{ Constituent } & \multicolumn{6}{|c|}{ Station name $1 /$} \\
\hline & $\begin{array}{c}\text { DOE-1 } \\
(\mu \mathrm{g} / \mathrm{L})\end{array}$ & $\begin{array}{r}\text { DOE-2 } \\
(\mu \mathrm{g} / \mathrm{L})\end{array}$ & $\begin{array}{r}\text { DOE-3 } \\
(\mu \mathrm{g} / \mathrm{L})\end{array}$ & $\begin{array}{r}\text { DOE-4 } \\
(\mu \mathrm{g} / \mathrm{L})\end{array}$ & $\begin{array}{l}\text { East } \\
\text { pond } \\
(\mu g / L)\end{array}$ & $\begin{array}{l}\text { West } \\
\text { pond } \\
(\mu \mathrm{g} / \mathrm{L})\end{array}$ \\
\hline \multicolumn{7}{|l|}{ Herbicides: } \\
\hline $\begin{array}{l}\text { Silvex } \\
2,4-\mathrm{D} \text {, total } \\
2,4-\mathrm{DP} \text {, total } \\
2,4,5-\mathrm{T} \text {, total }\end{array}$ & $\begin{array}{l}<0.01 \\
<0.01 \\
<0.01 \\
<0.01\end{array}$ & $\begin{array}{l}<0.01 \\
<0.01 \\
<0.01 \\
<0.01\end{array}$ & $\begin{array}{l}<0.01 \\
<0.01 \\
<0.01 \\
<0.01\end{array}$ & $\begin{array}{l}<0.01 \\
<0.01 \\
<0.01 \\
<0.01\end{array}$ & $\begin{array}{l}<0.01 \\
<0.01 \\
<0.01 \\
<0.01\end{array}$ & $\begin{array}{l}<0.01 \\
<0.01 \\
<0.01 \\
<0.01\end{array}$ \\
\hline \multicolumn{7}{|l|}{ Insecticides: } \\
\hline $\begin{array}{l}\text { Aldrin, total } \\
\text { Chlordane, total } \\
\text { DDD, total } \\
\text { DDE, total } \\
\text { DDT, total }\end{array}$ & $\begin{array}{l}<0.01 \\
<0.1 \\
<0.01 \\
<0.01 \\
<0.01\end{array}$ & $\begin{array}{l}<0.01 \\
<0.1 \\
<0.01 \\
<0.01 \\
<0.01\end{array}$ & $\begin{array}{l}<0.01 \\
<0.1 \\
<0.01 \\
<0.01 \\
<0.01\end{array}$ & $\begin{array}{l}<0.01 \\
<0.1 \\
<0.01 \\
<0.01 \\
<0.01\end{array}$ & $\begin{array}{l}<0.01 \\
<0.1 \\
<0.01 \\
<0.01 \\
<0.01\end{array}$ & $\begin{array}{l}<0.01 \\
<0.1 \\
<0.01 \\
<0.01 \\
<0.01\end{array}$ \\
\hline $\begin{array}{l}\text { Dieldrin, total } \\
\text { Endosulfan, I, total } \\
\text { Endrin, total } \\
\text { Gross PCB's, total } \\
\text { Gross PCN's, total }\end{array}$ & $\begin{array}{l}<0.01 \\
<0.01 \\
<0.01 \\
<0.1 \\
<0.1\end{array}$ & $\begin{array}{l}<0.01 \\
<0.01 \\
<0.01 \\
<0.1 \\
<0.1\end{array}$ & $\begin{array}{l}<0.01 \\
<0.01 \\
<0.01 \\
<0.1 \\
<0.1\end{array}$ & $\begin{array}{l}<0.01 \\
<0.01 \\
<0.01 \\
<0.1 \\
<0.1\end{array}$ & $\begin{array}{l}<0.01 \\
<0.01 \\
<0.01 \\
<0.1 \\
<0.1\end{array}$ & $\begin{array}{l}<0.01 \\
<0.01 \\
<0.01 \\
<0.1 \\
<0.1\end{array}$ \\
\hline $\begin{array}{l}\text { Heptachlor, total } \\
\text { Heptachlor, epoxide, } \\
\text { total } \\
\text { Lindane, total } \\
\text { Methoxychlor, total } \\
\text { Mirex, total }\end{array}$ & $\begin{array}{l}<0.01 \\
<0.01 \\
<0.01 \\
<0.01 \\
<0.01\end{array}$ & $\begin{array}{l}<0.01 \\
<0.01 \\
<0.01 \\
<0.01\end{array}$ & $\begin{array}{l}<0.01 \\
<0.01 \\
<0.01 \\
<0.01\end{array}$ & $\begin{array}{l}<0.01 \\
<0.01 \\
<0.01 \\
<0.01\end{array}$ & $\begin{array}{l}<0.01 \\
<0.01 \\
<0.01 \\
<0.01\end{array}$ & $\begin{array}{l}<0.01 \\
<0.01 \\
<0.01 \\
<0.01\end{array}$ \\
\hline $\begin{array}{l}\text { Perthane, total } \\
\text { Toxaphene, total }\end{array}$ & $\begin{array}{l}<0.1 \\
<1\end{array}$ & $\begin{array}{l}<0.1 \\
<1\end{array}$ & $\begin{array}{l}<0.1 \\
<1\end{array}$ & $\begin{array}{l}<0.1 \\
<1\end{array}$ & $\begin{array}{l}<0.1 \\
<1\end{array}$ & $\begin{array}{l}<0.1 \\
<1\end{array}$ \\
\hline
\end{tabular}

1/ Station name and corresponding identification number and (1atitude and longitude)

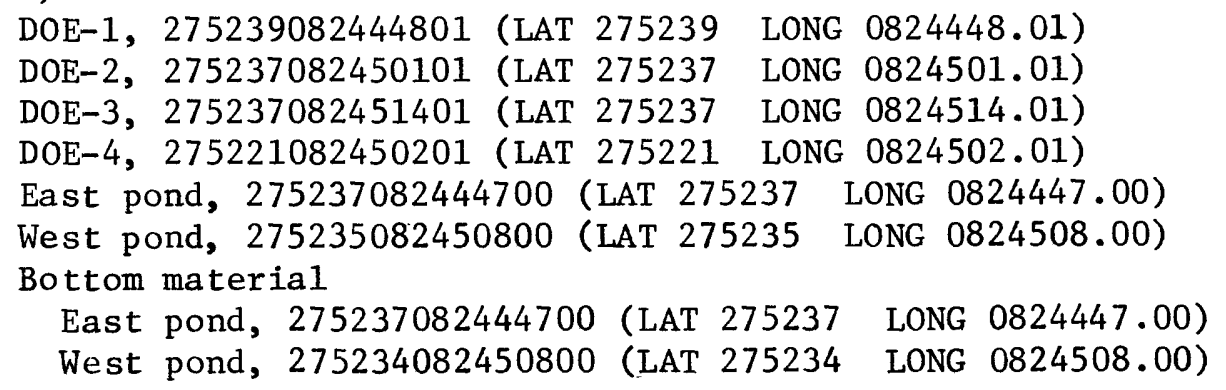




\begin{tabular}{|c|c|c|}
\hline \multirow[b]{2}{*}{ Constituent } & \multicolumn{2}{|c|}{ Station name $1 /$} \\
\hline & $\begin{array}{l}\text { East pond } \\
\text { bottom material } \\
(\mu \mathrm{g} / \mathrm{kg})\end{array}$ & $\begin{array}{l}\text { West pond } \\
\text { bottom material } \\
(\mu g / \mathrm{kg})\end{array}$ \\
\hline \multicolumn{3}{|l|}{ Herbicides: } \\
\hline $\begin{array}{l}2,4-\mathrm{D}- \\
2,4-\mathrm{DP}- \\
2,4,5-\mathrm{T} \\
\text { Silvex }\end{array}$ & $\begin{array}{l}<0.1 \\
<0.1 \\
<0.1 \\
<0.1\end{array}$ & $\begin{array}{l}<0.1 \\
<0.1 \\
<0.1 \\
<0.1\end{array}$ \\
\hline \multicolumn{3}{|l|}{ Insecticides: } \\
\hline $\begin{array}{l}\text { Aldrin }-1 \\
\text { Chlordane } \\
\text { DDD } \\
\text { DDE - }\end{array}$ & $\begin{array}{l}<0.1 \\
28 \\
19 \\
5.5 \\
<0.1\end{array}$ & $\begin{array}{l}<0.1 \\
3 \\
<0.1 \\
<0.1 \\
<0.1\end{array}$ \\
\hline $\begin{array}{l}\text { Diazinon } \\
\text { Dieldrin } \\
\text { Endosulfan } \\
\text { Endrin } \\
\text { Ethion }\end{array}$ & $\begin{array}{l}<0.1 \\
<0.1 \\
<0.1 \\
<0.1 \\
<0.1\end{array}$ & $\begin{array}{r}<0.1 \\
0.2 \\
<0.1 \\
<0.1 \\
<0.1\end{array}$ \\
\hline $\begin{array}{l}\text { Heptachlor } \\
\text { Heptachlor epoxide } \\
\text { Lindane } \\
\text { Malathion } \\
\text { Methoxychlor }\end{array}$ & $\begin{array}{l}<0.1 \\
<0.1 \\
<0.1 \\
<0.1 \\
<0.1\end{array}$ & $\begin{array}{l}<0.1 \\
<0.1 \\
<0.1 \\
<0.1 \\
<0.1\end{array}$ \\
\hline $\begin{array}{l}\text { Methylparathion } \\
\text { Me thyltrithion } \\
\text { Mirex } \\
\text { Parathion } \\
\text { Perthane }\end{array}$ & $\begin{array}{l}<0.1 \\
<0.1 \\
<0.1 \\
<0.1 \\
<1\end{array}$ & $\begin{array}{l}<0.1 \\
<0.1 \\
<0.1 \\
<0.1 \\
<1\end{array}$ \\
\hline $\begin{array}{l}\text { PCB' s - } \\
\text { PCN's } \\
\text { Toxaphene - } \\
\text { Trithion - }\end{array}$ & $\begin{array}{l}340 \\
<1 \\
<10 \\
<0.1\end{array}$ & $\begin{array}{r}230 \\
<1 \\
<10 \\
<0.1\end{array}$ \\
\hline
\end{tabular}




\section{SUPPLEMENT 6}

Water-Quality Data on Polynuclear Aromatic Hydrocarbons and Other

Hydrocarbons for Ground Water and Surface Water

[Concentrations are in micrograms per liter; (<) concentrations, if present, are less than detection limits]

$$
\text { DOE-1, } 275239082444801 \text { (LAT } 275239 \text { LONG 0824448.01) }
$$

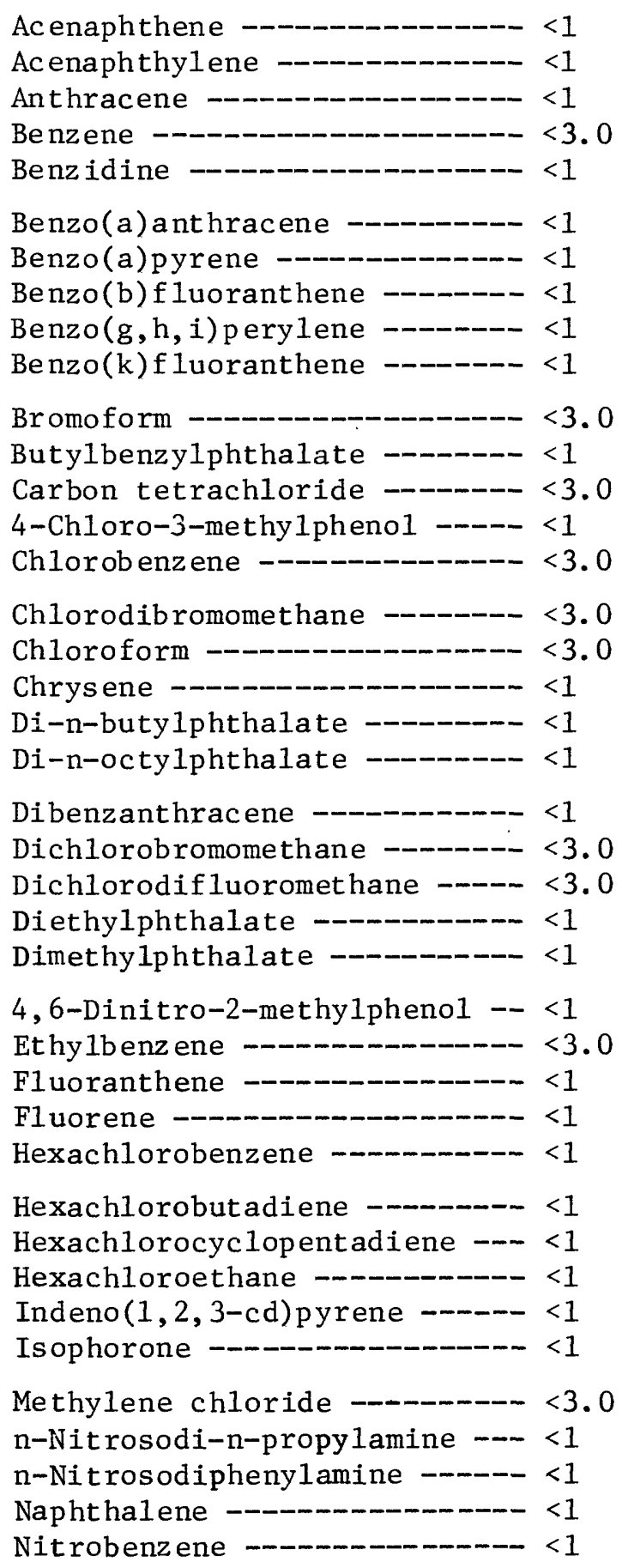

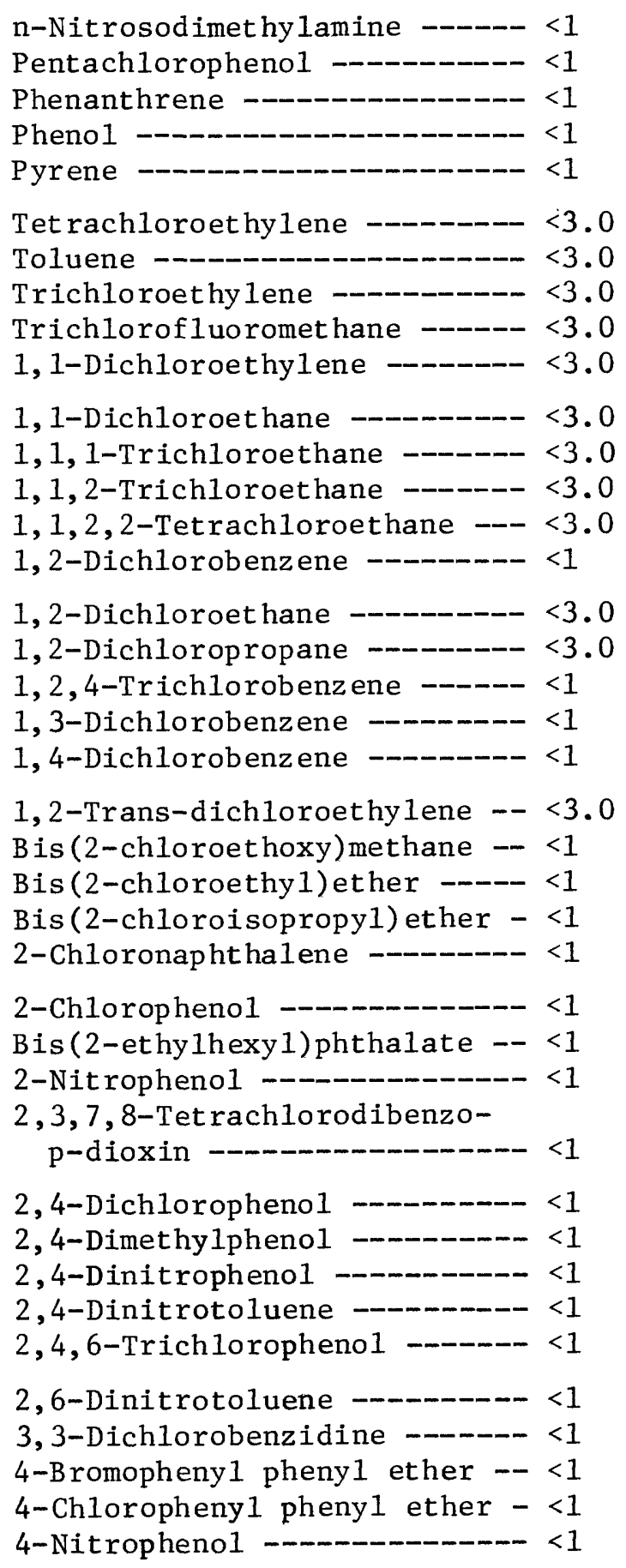






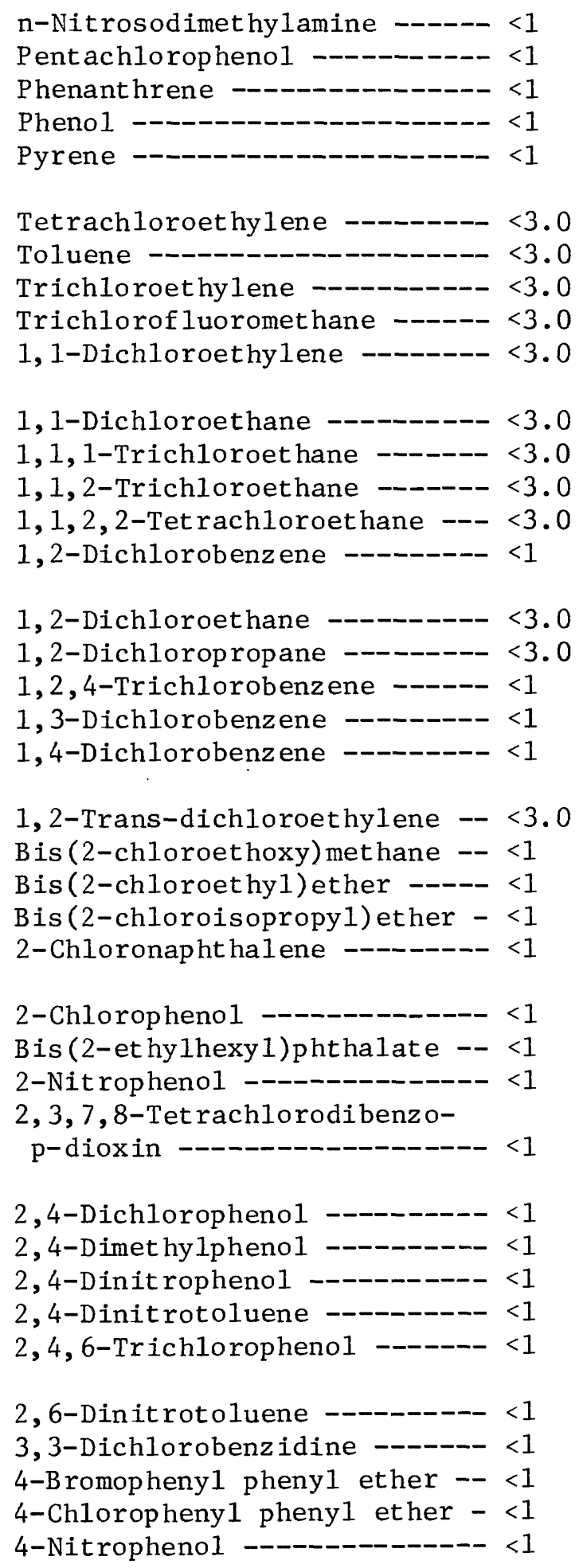




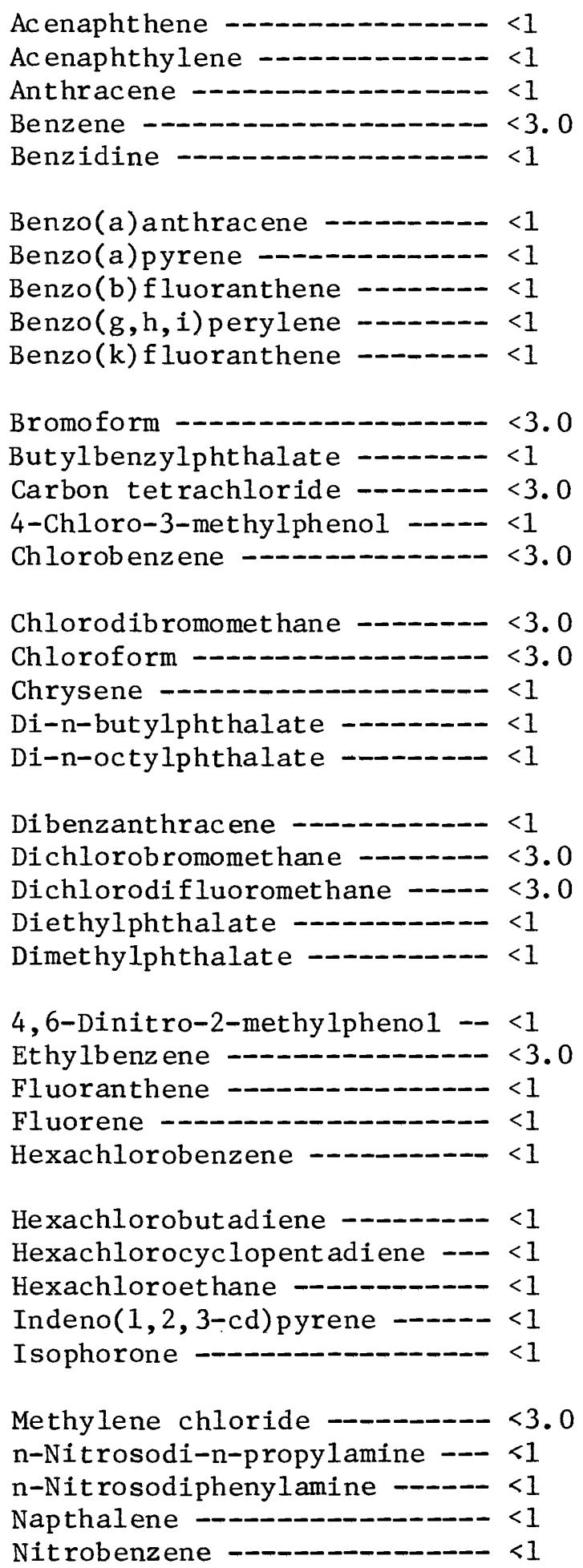

n-Nit rosodimethylamine -1
Pentachlorophenol
Phenant hrene
Phenol -1
Pyrene -1

Tet rachloroet hylene - - - - $<3.0$

Toluene - - - -

Trichloroethylene -- - - - - $<3.0$

Trichlorofluo romet hane - - - $<3.0$

1,1-Dichloroethylene - - - < $<.0$

1,1-Dichlo roet hane - - - - - <3. 0

$1,1,1-\operatorname{Trich} 1$ o roet hane - - - - $<3.0$

$1,1,2-$ Trichloroet hane - - - $<3.0$

$1,1,2,2-$ Tet rachloroet hane -- $<3.0$

1,2-Dichlorobenzene ------ <1

1,2-Dichloroet hane - - - - - <3.0

$1,2-$ Dichlo rop ropane - - - $<3.0$

$1,2,4-T r i c h l o$ robenzene - - - $<1$

1,3-Dichlorobenzene - - - - - <1

1,4-Dichlorobenzene - - - - - <1

1,2-Trans-dichloroet hylene - $<3.0$

Bis (2-chloroethoxy) methane - $<1$

Bis (2-chloroethyl)ether - - - <1

Bis (2-chloroisopropyl) ether - <1

2-Chloronaphthalene -- - - - - <1

2-Chlorophenol -- - - - - - < $<$

Bis (2-ethylhexy 1) phthalate - < 1

2-Nit ropheno1 -- - - - - - - < <1

$2,3,7,8$-Tet rachlorodibenzop-dioxin - -

2,4-Dichlorophenol - - - - < <1

2,4-Dimethylphenol _-_- _- $<1$

2,4-Dinit rophenol - - - - - $<1$

2,4-Dinitrotoluene ----- - - <1

$2,4,6-T r i c h l o r o p h e n o l-\infty-\infty<1$

2,6-Dinitrotoluene ---- - - $<1$

3,3-Dichlorobenzidine -- - - $<1$

4-Bromophenyl phenyl ether -- <1

4-Chlorophenyl phenyl ether - <1

4-Nitrophenol - - - - - - - - - <1

Total organic carbon ------ 70,000 


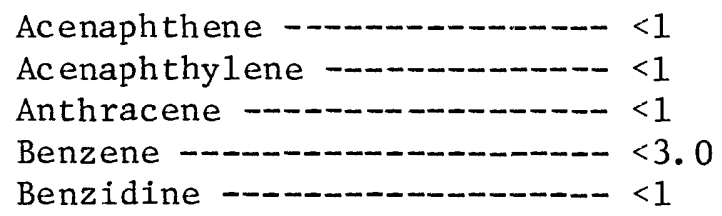

Benzo(a) anthracene --.-- - - $<1$

Benzo (a) pyrene - - - -

Benzo(b)fluoranthene -. - -.$-<1$

$\operatorname{Benzo}(\mathrm{g}, \mathrm{h}, \mathrm{i})$ perylene -..--.- $<1$

Benzo(k)fluoranthene --_-_-- $<1$

Bromoform -

Butylbenzylphthalate --.--- < <1

Carbon tetrachloride - - - $<3.0$

4-Chloro-3-methylphenol -- - $<1$

Chlorobenzene -

Chlorodibromomethane - - - $<3.0$

Chloroform -

Chrysene - - -

Di-n-butylphthalate --.-- $<1$

Di-n-octylphthalate - -

Dibenzant hracene - - - - $<1$

Dichlorobromomethane --.-- $<3.0$

Dichlorodifluoromethane - - - $<3.0$

Diethylph thalate - - - - $<1$

Dimethylphthalate --_-_-_ $<1$

4,6-Dinitro-2-methylpheno1 -- <1

Et hylbenzene --

F1uoranthene - -

Fluorene - -

Hexachlorobenzene --_-_-_- $<1$

Hexachlorobutadiene ------- <1

Hexachlorocyclopent adiene - - $<1$

Hexachloroethane --_--_-- $<1$

Indeno( $1,2,3-c d)$ pyrene -..-- $<1$

Isophorone - -

Methylene chloride - - - $<3.0$

n-Nitrosodi-n-propylamine -.- $<1$

n-Nitrosodiphenylamine -..-.- $<1$

Napthalene -

Nitrobenzene -
n-Nitrosodimethylamine - - - -1

Pentachlorophenol - - -

Phenanthrene --_-_-_-_-_--- $<1$

Phenol - -

Pyrene - -

Tetrachloroet hylene --- - - $<3.0$

Toluene - - -

Trichloroet hylene - - - - $<3.0$

Trichlorofluoromethane - - - $<3.0$

1,1-Dichloroethylene - - - $<3.0$

1,1-Dichloroethane -------- $<3.0$

$1,1,1$-Trich1oroethane -- - - $<3.0$

$1,1,2-\operatorname{Tr}$ ichloroet hane ----- $<3.0$

$1,1,2,2$-Tet rachloroet hane --- $<3.0$

1,2-Dichlorobenzene -.....- <1

1,2-Dichloroethane -- - - $<3.0$

1, 2-Dichlorop ropane --- - $<3.0$

1, 2, 4-Trichlorobenzene - - - $<1$

1, 3-Dichlorobenzene -.-.-- $<1$

1, 4-Dichlorobenzene -. - - $<1$

1,2-Trans-dichloroethylene -- $<3.0$

Bis (2-chloroet hoxy) methane -- $<1$

Bis (2-chloroethy1) ether - - - $<1$

Bis (2-chloroisop ropy 1 ) ether $-<1$

2-Chloronaphthalene - - - - $<1$

2-Chlorophenol -- - - - - $<1$

Bis (2-ethylhexy1) phthalate -- $<1$

2-Nitrophenol - - - - - $<1$

$2,3,7,8$-Tet rachlorodibenzop-dioxin - - 1

2,4-Dichlorophenol _-_-_-_- <1

2,4-Dimet hylphenol --_---- <1

2,4-Dinitrophenol _-_-_- $<1$

2,4-Dinitrotoluene -- - - $<1$

$2,4,6-$ Trichlorophenol - - - - $<1$

2,6-Dinitrotoluene -......- $<1$

3, 3-Dichlorobenzidine -.....- <1

4-Bromophenyl phenyl ether -- $<1$

4-Chlorophenyl phenyl ether $-<1$

4-Nitrophenol - - 


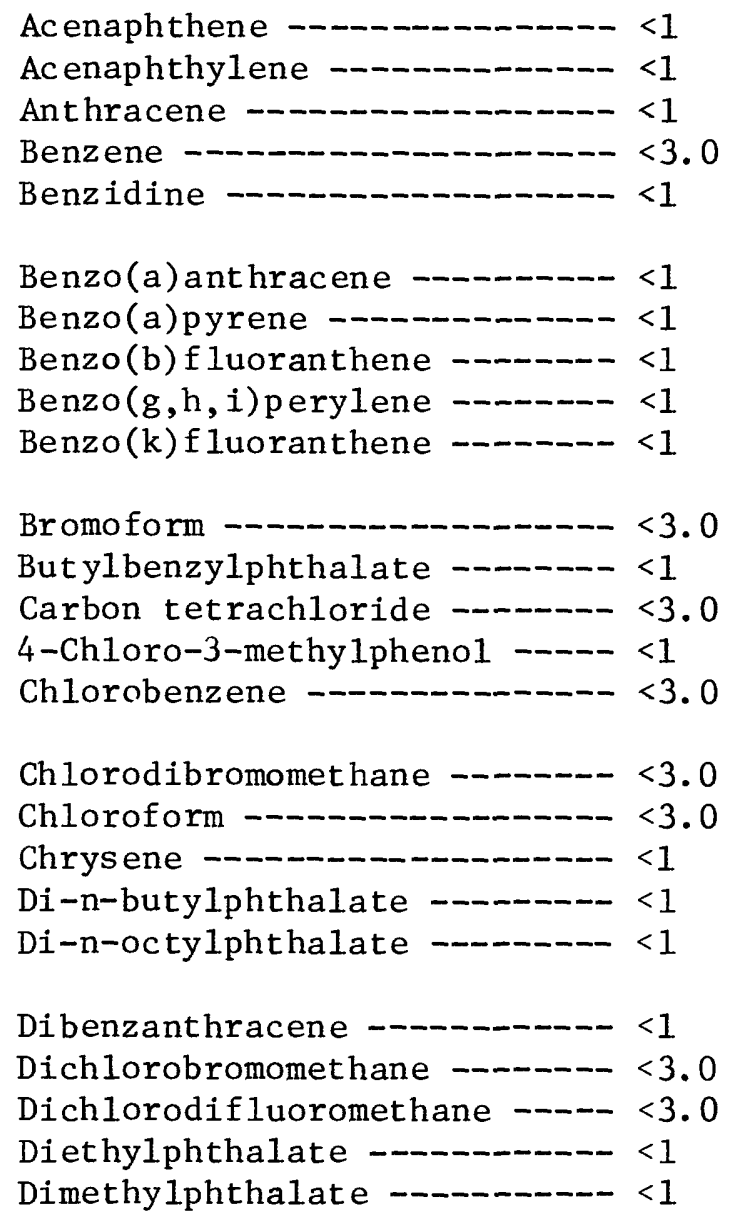

4,6-Dinitro-2-met hylphenol - $<1$

Ethylbenzene -

Fluoranthene -

Fluorene -

Hexachlorobenzene - -

Hexachlorobut adiene - _..._- $<1$

Hexachlorocyclopentadiene - - $<1$

Hexachloroethane - - - - - - $<1$

Indeno $(1,2,3-c d)$ pyrene -...- $<1$

Isophorone -

Methylene chloride - - - $<3.0$

n-Nitrosodi-n-propylamine -- $<1$

n-Nit rosodiphenylamine -....- $<1$

Nap thalene - -

Nitrobenzene

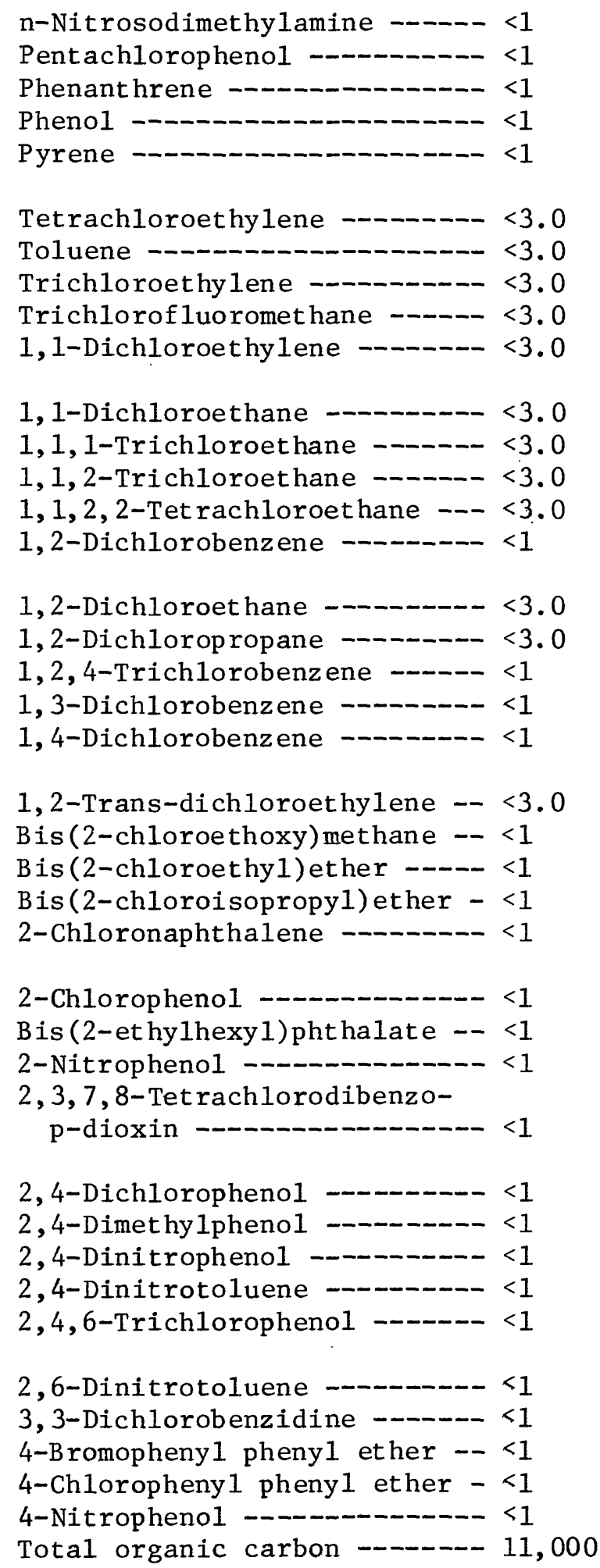




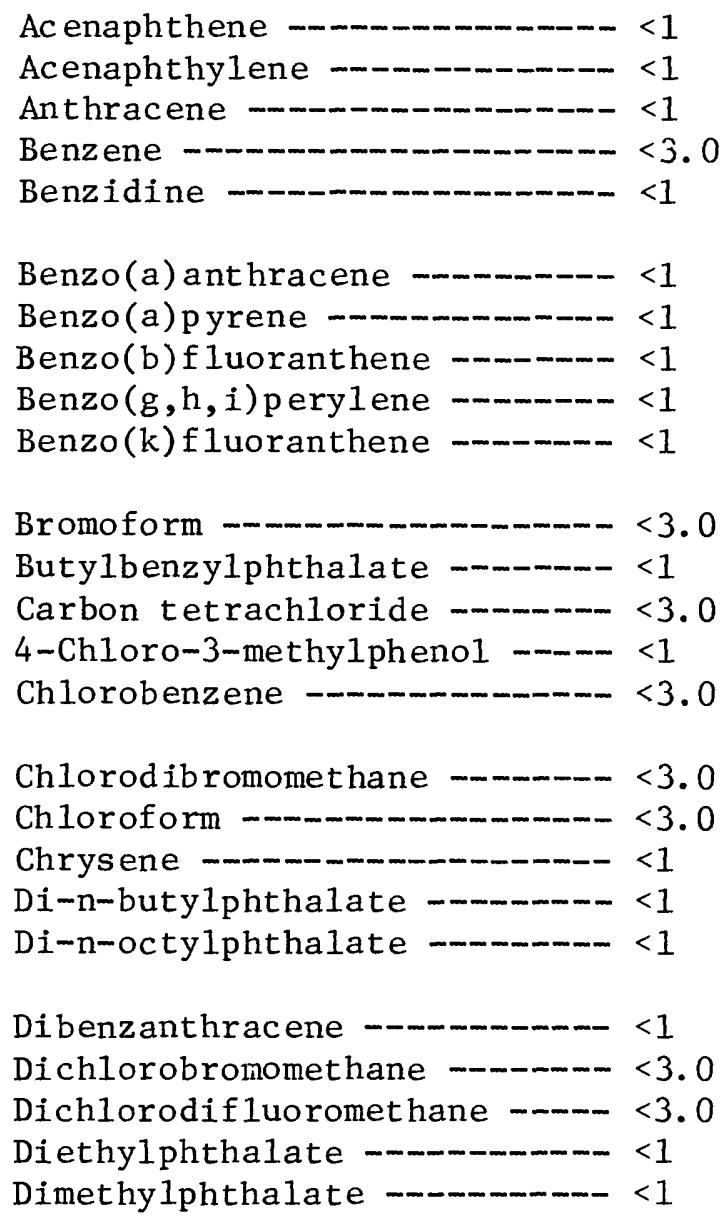

4, 6-Dinitro-2-methylpheno1 - < <1

Ethylbenzene - - $<3.0$

Fluoranthene -

Fluorene -

Hexachlorobenzene _-

Hexachlorobutadiene -- - - - $<1$

Hexachlorocyclopent adiene --- $<1$

Hexachloroethane - - - $<1$

Indeno $(1,2,3-c d)$ pyrene - - - $<1$

Isophorone -

Methylene chloride - - - - $<3.0$

n-Nitrosodi-n-propylamine -- $<1$

n-Nitrosodiphenylamine - - - $<1$

Napthalene - - $<1$

Nitrobenz ene - -
n-Nitrosodimet hylamine
Pentachlorophenol
Phenant hrene
Phenol -
Pyrene

Tet rachloroethylene - - - $<3.0$

Toluene -

Trichloroethylene - $<3.0$

Trichlorofluoromethane - - - $<3.0$

1,1-Dichloroethylene -...- $<3.0$

1,1-Dichloroethane --- -- - $<3.0$

$1,1,1-$ Trichloroethane - - - $<3.0$

1,1,2-Trichloroethane - -..-- $<3.0$

$1,1,2,2$-Tet rachloroet hane --- $<3.0$

1,2-Dich1orobenzene -.....- $<1$

1,2-Dichloroethane - - - $<3.0$

1,2-Dichloropropane -- - $<3.0$

1,2,4-Trichlorobenzene ----- $<1$

1,3-Dichlorobenzene -- - - - <1

1,4-Dichlorobenzene - - - - < $<$

1, 2-Trans-dichloroet hylene -- $<3.0$

Bis (2-chloroethoxy)methane -- $<1$

Bis (2-chloroethy 1 ) ether -..- $<1$

Bis (2-chloroisopropyl)ether - <1

2-Chloronaphthalene --- - - - <1

2-Chlorophenol - -

Bis (2-ethylhexy 1 ) phthalate $--<1$

2-Nitropheno1 - - $<1$

2, 3, 7, 8-Tetrachlorodibenzop-dioxin - - $<1$

2,4-Dich1orophenol -- - $<1$

2,4-Dimethylphenol _-_-_-_- $<1$

2,4-Dinitrophenol _-_-_-_- $<1$

2,4-Dinit rotoluene - - - - $<1$

2,4,6-Trichlorophenol - - - - < <1

2,6-Dinitrotoluene -..._- $<1$

3,3-Dichlorobenzidine -...... $<1$

4-Bromophenyl phenyl ether - $<1$

4-Chlorophenyl phenyl ether $-<1$

4-Nitrophenol _- 


\section{SUPPLEMENT 7}

Water-Quality Data on Polynuclear Aromatic Hydrocarbons and Other Hydrocarbons in Bottom Material

[Concentrations in micrograms per kilogram; ( $<$ ) concentrations, if present, are less than detection limits]

East pond bottom material, 275237082444700 (LAT 275237 LONG 0824447.00)

\begin{tabular}{|c|c|}
\hline & \\
\hline cenaphthylene & \\
\hline nthracene - & \\
\hline is (2-chloroisopropy 1 ) ether - & \\
\hline is (2-chloroethoxy) methane -- & \\
\hline is $(2-$ chloroethy 1$)$ ether & \\
\hline Bis (2-ethylhexyl) phthalate -- & \\
\hline Benzidine -- - & \\
\hline Benzoanthracene -------- & \\
\hline enzo (b) fluoranthene -- & \\
\hline thene -------- & \\
\hline perylene - & \\
\hline 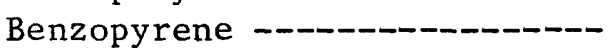 & \\
\hline enyl pheny 1 ether -- & \\
\hline Butylbenzylphthalate --_---- & \\
\hline thylphenol ----- & \\
\hline henol & \\
\hline halene --ー-ー-ー-- & \\
\hline 4-Chlorophenyl phenyl ether - & \\
\hline Chrysene - - & \\
\hline late -ーーーーーーー- & \\
\hline Dibenz $(a, h)$ anthracene & \\
\hline 2,4-Dichlorophenol _-__-_- & \\
\hline Diethylphthalate - & \\
\hline 2,4-Dimethylphenol -_- & \\
\hline e-------- & \\
\hline -met hylphenol -- & \\
\hline enol - - & \\
\hline late - - - - & \\
\hline
\end{tabular}

\begin{tabular}{|c|c|}
\hline Fluoranthene - & \\
\hline 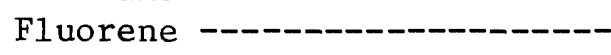 & \\
\hline Hexachlorobenzene & \\
\hline exachlorobutadiene -- & \\
\hline exachloroet hane ------------ & \\
\hline Hexachlorocyclopentadiene --- & \\
\hline denopyrene -- - - - - - - - - - & \\
\hline sophorone -- - - - - & \\
\hline 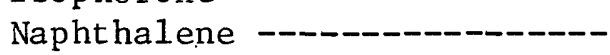 & \\
\hline n-Nitrosodimethylamine ------ & \\
\hline -Nit rosodiphenylamine ------- & \\
\hline n-Nitrosodi-n-propylamine - & \\
\hline Nitrobenzene & \\
\hline 1orophenol --------- & \\
\hline hrene -- - - & \\
\hline 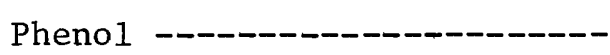 & \\
\hline $\begin{array}{l}\text { Pyrene } \\
2,3,7,8-\text { Tet rachlorodibenzo- }\end{array}$ & \\
\hline p-dioxin - & \\
\hline Trichlorophenol ----------- & \\
\hline $1,2,4-\operatorname{Tr}$ ichlorobenzene -- & \\
\hline 1,2-Dichlorobenzene & \\
\hline 1,3-Dichlorobenzene - - & $<$ \\
\hline 1,4-Dichlorobenzene ----- & \\
\hline 2-Nitrophenol & \\
\hline 2,4-Dinitrotoluene --_--- & \\
\hline 2,6-Dinitrotoluene - & \\
\hline hlorobenzidine ----- & \\
\hline phenol _- - - - & \\
\hline
\end{tabular}


West pond bottom material, 275234082450800 (LAT 275234 LONG 0824508.00)

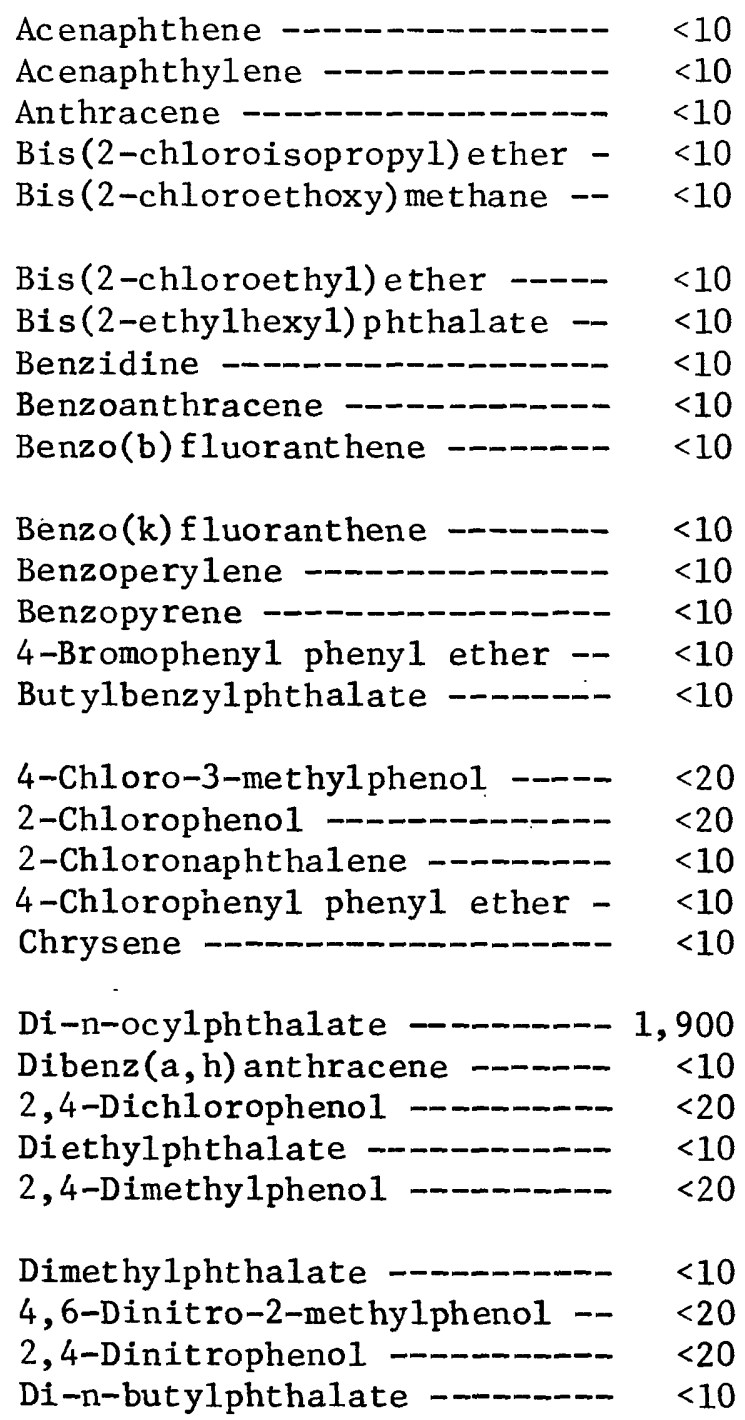

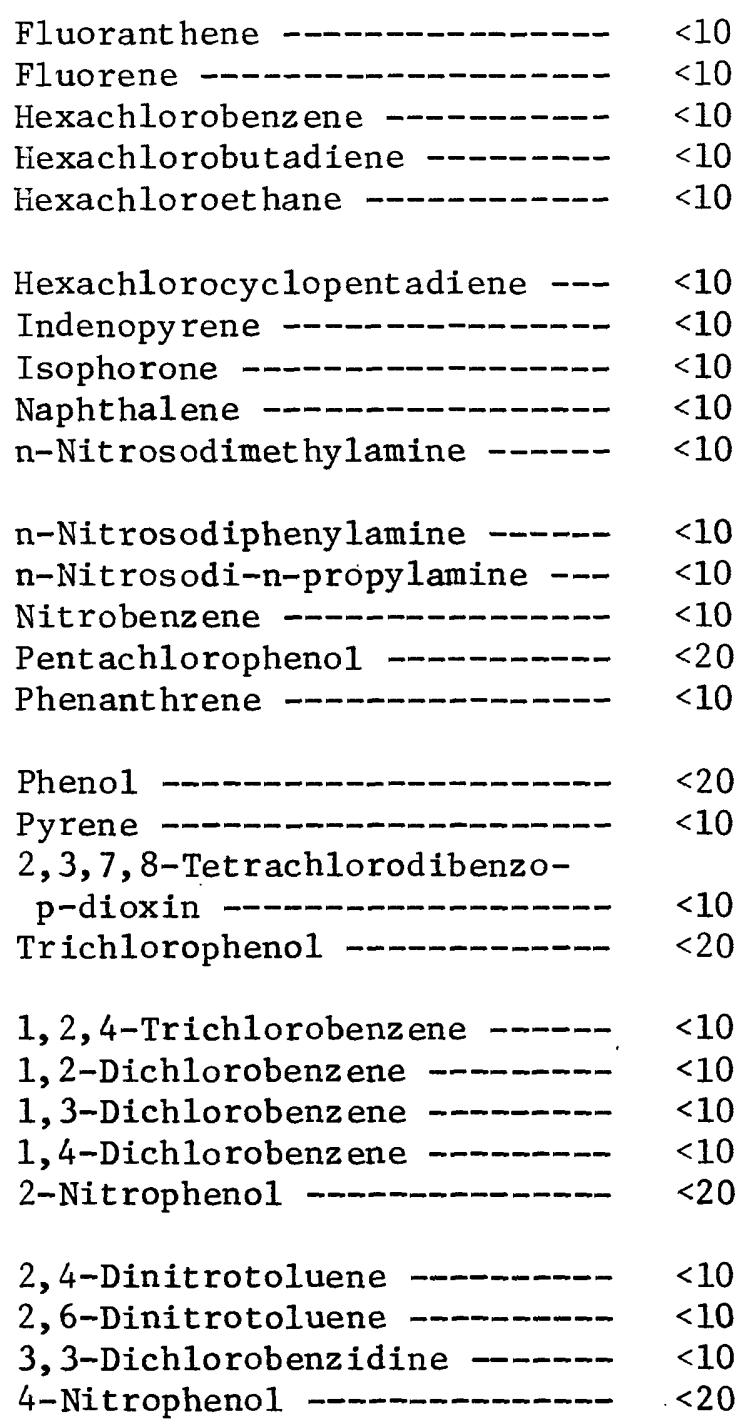


Water-Quality Data on Nonpriority Pollutants Found in Ground Water, Surface Water, and Bottom Material

[Concentrations in milligrams per liter, except as noted; $\mu \mathrm{g} / \mathrm{kg}$, micrograms per liter]

\begin{tabular}{|c|c|c|c|}
\hline Site & Nonpriority pollutant & Concentration & Qualifie \\
\hline \multicolumn{4}{|c|}{ Water Samples } \\
\hline \multirow[t]{6}{*}{ DOE-1 } & 2-Pent anone, 3-Methy 1 & -- & 3 \\
\hline & Not identified & -- & 3 \\
\hline & Not identified & -- & 3 \\
\hline & Not identified & -- & - \\
\hline & Not identified & -- & - \\
\hline & Bis(2-ethylhexy1) phthalate & -- & 3 \\
\hline \multirow[t]{9}{*}{ DOE-2 } & 2-Pent anone, 3-Methy1 & -- & 3 \\
\hline & Not identified & -- & - \\
\hline & Not identified & -- & - \\
\hline & Not identified & -- & - \\
\hline & Not identified & -- & - \\
\hline & Not identified & -- & - \\
\hline & Phenol, 3-Ethy1 & 1.2 & 1,2 \\
\hline & Not identified & -- & - \\
\hline & Bis (2-ethylhexy1)phthalate & -- & 3 \\
\hline \multirow[t]{5}{*}{ DOE-3 } & Not identified & -- & - \\
\hline & 2-Pent anone, 3-Methy1 & -- & 3 \\
\hline & Not identified & -- & 3 \\
\hline & Not identified & -- & 3 \\
\hline & Bis (2-ethylhexy 1 ) phthalate & -- & 3 \\
\hline \multirow[t]{6}{*}{ DOE-4 } & 2-Pent anone, 3-Methy 1 & -- & 3 \\
\hline & Not identified & -- & - \\
\hline & Not identified & -- & 3 \\
\hline & Not identified & -- & - \\
\hline & Not identified & -- & - \\
\hline & Bis (2-et hy lhexy 1 )phthalate & -- & 3 \\
\hline \multirow{7}{*}{$\begin{array}{l}\text { East } \\
\text { pond }\end{array}$} & 2-Pent anone, 3-Methy 1 & -- & 3 \\
\hline & Not identified & -- & - \\
\hline & Not identified & - & 3 \\
\hline & Not identified & -- & - \\
\hline & Not identified & -- & 3 \\
\hline & Bis (2-ethylhexy 1 )phthalate & -- & 3 \\
\hline & Not identified & -- & - \\
\hline
\end{tabular}

Footnote is at end of table. 


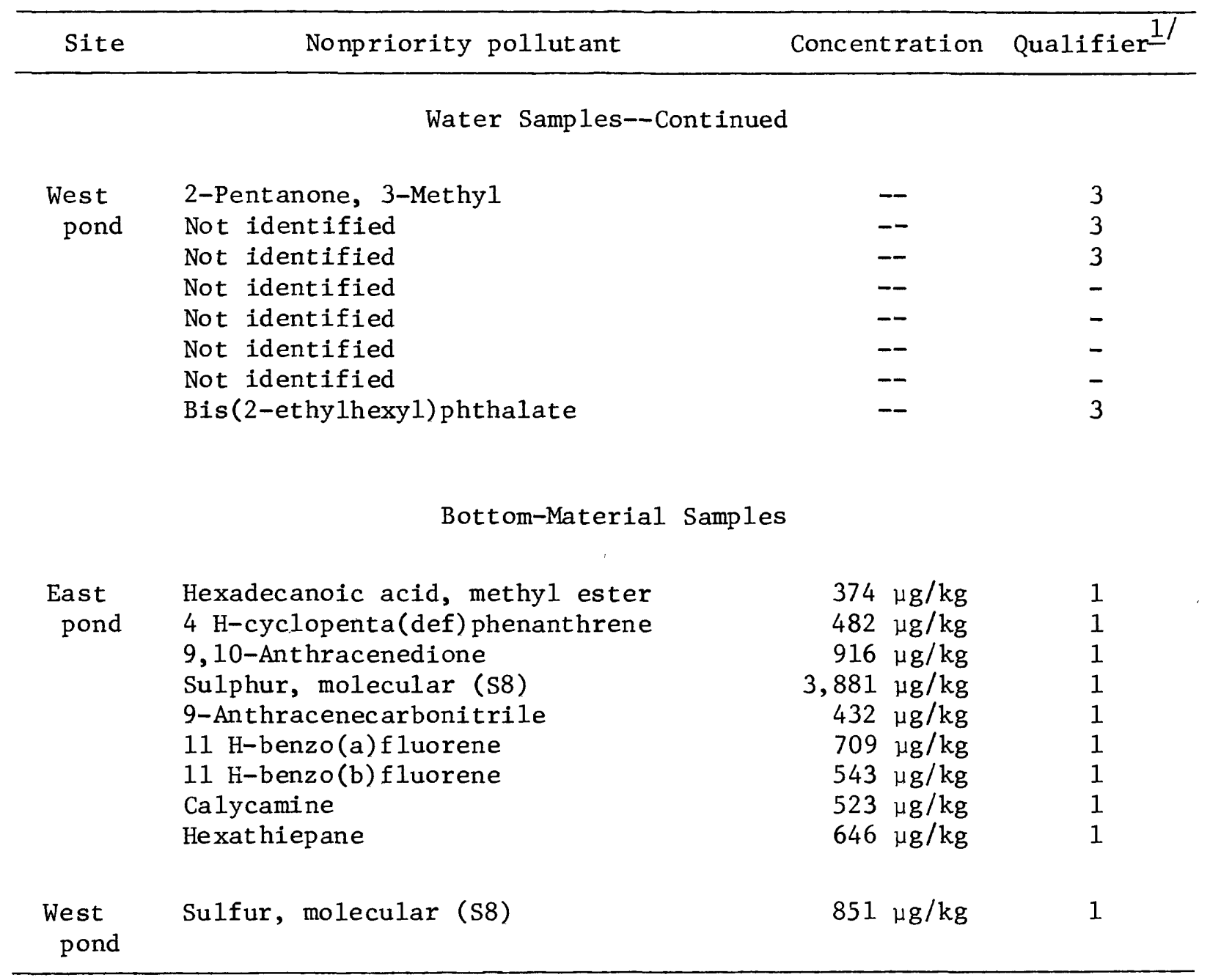

1/ Qualifiers:

1 - Compound was identified only by comparison of the unknown peak with mass spectra stored in the National Bureau of Standards (NBS) library. No authentic standard available; concentration reported is semiquantitative and based only on the response factor of the internal standard added to the sample immediately before GC/MS analysis.

2 - Reported concentration is an estimated value. Established reporting limit $=5.0 \mu \mathrm{g} / \mathrm{L}$ (water); $200 \mu \mathrm{g} / \mathrm{kg}$ (sediment).

3 - Contaminant, also present in reagent/glassware blank. 